
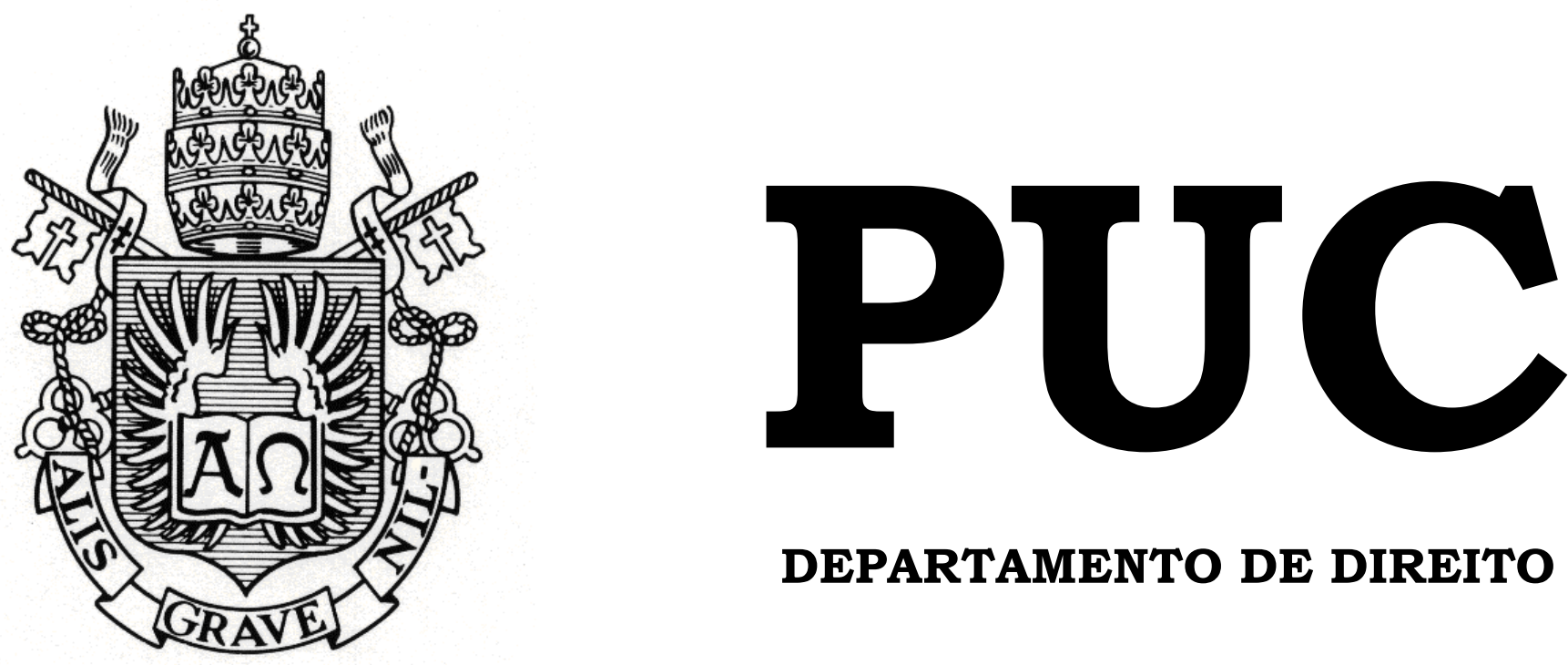

DEPARTAMENTO DE DIREITO

A invenção e o invento do empregado sob a ótica trabalhista

por

Renata Monteiro de Almeida

ORIENTADORA: Maria Celeste Simões Marques 2009.1

PONTIFÍCIA UNIVERSIDADE CATÓLICA DO RIO DE JANEIRO RUA MARQUÊS DE SÃO VICENTE, 225 - CEP 22453-900 RIO DE JANEIRO - BRASIL 


\title{
A invenção e o invento do empregado sob a ótica trabalhista
}

\author{
por \\ Renata Monteiro de Almeida
}

Monografia apresentada ao Departamento de Direito da Pontifícia Universidade Católica do Rio de Janeiro (PUC-Rio) como requisito parcial para a obtenção do Título de Bacharel em Direito.

Orientadora: Maria Celeste Simões Marques 
Para meu querido avô, que já se foi e me deixa saudades. 


\section{Agradecimentos}

A minha orientadora Professora Maria Celeste que me estimulou com preciosos conselhos e auxílios bibliográficos.

Aos professores que participaram da Comissão examinadora.

Aos meus pais e ao Marcel, pela compreensão, apoio e carinho nos momentos difíceis.

Aos funcionários da Biblioteca do Tribunal de Justiça e da Biblioteca do INPI, pela paciência em minhas incansáveis pesquisas.

À Lívia, Aline, Elaine e ao Milton pelas palavras carinhosas de incentivo. 


\section{Resumo}

Almeida, Renata Monteiro de. A invenção e o invento do empregado sob a ótica trabalhista. Rio de Janeiro, 2009. 63 p. Trabalho Monográfico - Departamento de Direito, Pontifícia Universidade Católica do Rio de Janeiro.

No contexto atual do mundo globalizado, inovar passou a ser uma necessidade dos países para fazer frente à nova realidade do bem intangível como instrumento gerador de riquezas e de poder político. Nesta seara, as empresas, com o escopo de se tornarem mais competitivas, revelam uma crescente preocupação em seguir esta tendência de desenvolvimento e apropriação de bens imateriais. Neste contexto, o empregado inventor, no bojo da relação empregatícia, em desigualdade de forças, traz à baila a discussão jurídica sobre os direitos que porventura detenha sobre o invento ou invenção por ele desenvolvido na constância da relação de emprego. Assim, o presente trabalho tem por objetivo revelar as controvérsias doutrinárias e jurisprudenciais trabalhistas oriundas dessa delicada relação empregatícia, perpassando, para tanto, em conceitos de Direito Intelectual. Por fim, o estudo que se segue fica como um convite ao debate deste tema de grande importância e ainda tão pouco difundido na doutrina e na jurisprudência brasileiras.

\section{Palavras-chave}

Propriedade Intelectual; Direito do Trabalho; invenção; invento; contrato de emprego; jurisprudência trabalhista. 


\section{Sumário}

1. Introdução

2. A Interdisciplinaridade entre os Conceitos e Categorias da Propriedade Intelectual e o Direito do Trabalho

2.1. Noções Gerais da Propriedade Intelectual e a Titularidade dos Inventos ou Invenções

2.2. O Patrimônio Intangível da Empresa e as Relações Trabalhistas

2.3. A Proteção ao Inventor em Sede Constitucional

2.4. A Proteção ao Inventor na Legislação Ordinária

2.5. O Modelo de Utilidade Patenteável

3. Algumas Questões Trabalhistas Envolvendo o Empregado Inventor

3.1. A Relação Empregador / Empregado Inventor

3.2. Do Pagamento Devido ao Empregado

3.3. Dos Danos Morais Devidos ao Empregado

3.4. Da Competência da Justiça do Trabalho

4. As Espécies de Invenção ou Invento do Empregado

4.1. Das Invenções ou Inventos de Serviço

4.1.1. A Remuneração do Empregado Inventor nas Invenções ou Inventos de Serviço

4.1.2. O Artigo 88, $\S 2^{\circ}$, da Lei $9.279 / 1996$ e a Tentativa de Coibir o Cometimento de Fraude pelo Empregado

4.2. Das Invenções ou Inventos Livres

4.3. Das Invenções ou Inventos Mistos ou Dependentes ou Ocasionais 
"A menor distância entre dois pontos é sempre um ponto de vista”.

Manuel Bandeira 


\section{Introdução}

Ainda que as disputas inerentes à relação empregado/empregador se percam no tempo e na densa literatura sobre o tema, em razão da acelerada dinâmica social, vislumbra-se que este antagonismo de interesses não se viu esgotado de abordagem doutrinária, pois a cada nova realidade social, ele ganha nova roupagem que torna esta temática sempre atual e passível de discussões teóricas e/ou práticas.

Assim, o presente trabalho, ainda que se paute nesta antiga e delicada relação empregatícia, mostra-se atual, visto que aborda os direitos do empregado inventor, tema que ainda carece de muitos debates doutrinários e jurisprudenciais. Uma das dificuldades deste tema reside na sua interdisciplinaridade, já que exige conhecimentos tanto de Direito Intelectual, quanto de Direito do Trabalho, o que o leva a ser abarcado de forma escassa e insuficiente por ambos os campos do conhecimento.

Dessa forma, este trabalho buscou realizar um diálogo entre o preceituado pelos autores de propriedade intelectual, em especial no campo da propriedade industrial, e o exarado pela doutrina e jurisprudência trabalhistas, que ao fim e ao cabo, devem analisar os direitos do inventor para pôr fim às lides existentes sob sua competência.

Dois foram os cortes realizados na delimitação dos assuntos abordados pelo estudo que se segue: $\mathrm{O}$ primeiro foi em relação às modalidades de obras realizadas pelo empregado, na constância do contrato de emprego, já que, nos ditames do Direito Intelectual, estas são inúmeras. Nesta seara, optou-se por tratar eminentemente das criações passíveis de patenteabilidade, que, nos termos da lei, são as invenções e os modelos de utilidade.

Em segundo lugar, cumpre informar que o estudo foi limitado às lides de competência da Justiça do Trabalho. No entanto, tendo em vista que a Emenda Constitucional $n^{\circ}$ 45/2004 expandiu a competência da Especializada, 
que passou a abarcar não apenas a relação de emprego (espécie), como também as relações de trabalho (gênero), é importante salientar que este trabalho restringiu-se eminentemente às relações de emprego, tendo sido deixadas de fora as discussões que envolvem as especificidades das diversas hipóteses de contratos de trabalho, já que, para tanto, seria necessário a realização de um outro estudo para fazer jus à temática em questão.

A escolha do tema fundou-se tanto no trabalho que desempenho no Instituto Nacional da Propriedade Industrial, como Técnica em Planejamento, Gestão e Infra-Estrutura em Propriedade Industrial, quanto na escassez dos artigos e livros que tratam dessa temática de suma importância para o desenvolvimento tecnológico e social do país. Essa escassez motivou a pesquisa e a proposição deste debate doutrinário, haja vista que, nesta seara, é grande a falta de informação dos empregados inventores sobre os seus direitos, bem como também é clara a intenção das grandes organizações em não difundir tal sorte de conhecimento, afinal repartir os proveitos econômicos da obra não é interessante para o empregador.

Assim, tendo em vista que este trabalho objetiva difundir este tema tão importante, no planejamento do trabalho, optei por um nível de exposição acessível a leitores não previamente familiarizados com as temáticas estudadas. Para tanto, iniciei o trabalho abordando eminentemente conceitos advindos dos Direitos Intelectuais, de forma que, o leitor não se perca no decorrer da leitura em razão de alguma terminologia não conhecida ou olvidada. É importante salientar que ao longo do trabalho acabo por utilizar indiscriminadamente os vocábulos "inventos" e "invenções", no entanto, é importante observar que parte da doutrina especializada utiliza a palavra “inventos" para se referir aos modelos de utilidades e o termo "invenções" como aplicável às atividades inventivas dotadas de inovação plena.

Para dar início ao trabalho, parti das classificações teóricas que envolvem os direitos intelectuais. Para aclarar os conceitos imprescindíveis ao 
entendimento dos direitos do inventor, no Capítulo $A$ interdisciplinaridade entre os conceitos e categorias da Propriedade Intelectual e o Direito do Trabalho, perpassei pelas noções gerais da propriedade intelectual que configuram a titularidade dos inventos ou invenções na pessoa do inventor, bem como abarquei a proteção devida a este inventor em sede constitucional e em sede de legislação ordinária. Em seguida, no capítulo Algumas questões trabalhistas envolvendo o empregado inventor, a partir da relação empregador e empregado foi realizada uma trajetória que culminou nas discussões atinentes às parcelas devidas ao criador e à competência da Justiça do Trabalho para apreciar lides desta natureza.

Por fim, por intermédio da reconstrução desta trajetória, será possível conhecer, através do Capítulo As espécies de invenção ou invento do empregado, como os doutrinadores brasileiros têm recepcionado o novo Código da Propriedade Intelectual (Lei 9.279/1996), nos ditames dos diferentes tipos de invenções ou inventos. Por último, dialogarei a doutrina, até então existente, com a jurisprudência disponível nos sites de todos os Tribunais Regionais do Trabalho, bem como no Tribunal Superior do Trabalho, de forma que seja possível depreender o tratamento nacional que vem sendo dado ao tema. Dessa forma, o presente trabalho reúne os entendimentos consolidados, até então, sobre as invenções ou inventos do empregado, bem como aborda peculiaridades que ainda merecem ser mais debatidas pela doutrina e enfrentadas pelos tribunais trabalhistas em casos concretos.

Por último, é importante assinalar que para a realização deste trabalho foram utilizadas as normas para elaboração e apresentação da monografia do Departamento de Direito da PUC-Rio, bem como as normas para apresentação de teses e dissertações dispostas pela Pós-graduação da PUC-Rio. 


\section{A INTERDISCIPLINARIDADE ENTRE OS CONCEITOS E CATEGORIAS DA PROPRIEDADE INTELECTUAL E O DIREITO DO TRABALHO:}

\subsection{NOÇÕES GERAIS DA PROPRIEDADE INTELECTUAL E A TITULARIDADE DOS INVENTOS OU INVENÇÕES:}

A inteligência, o trabalho intelectual e o engenho ${ }^{1}$ humanos sempre culminaram em toda a sorte de produções literárias, artísticas, científicas e industriais $^{2}$, algumas das quais, por mais remotas que sejam, em função da atemporalidade que lhes é intrínseca, continuam a fazer parte de nossas vidas cotidianas.

São estas criações do espírito humano conhecidas como bens imateriais $^{3}$, haja vista que a intelectualidade é a fonte destes bens, sendo, estes, os geradores dos bens materiais ${ }^{4}$. Denis Borges Barbosa ${ }^{5}$ explica a noção de bem imaterial por intermédio da categoria jurídica da especificação, segundo a qual a espécie nova será do especificador se o seu valor exceder consideravelmente o da matéria-prima. Segundo este raciocínio, o artigo 1.270 do Código Civil de $2002^{6}$ expõe como se dá a criação e a apropriação do bem imaterial; ou seja, "seja essa matéria prima

\footnotetext{
1 "La denominazione opere dell'ingegno è molto lata. Essa, infantti, abbraccia non solo le opere litterarie, scientifiche ed artistiche, ma anche i disegni e modelli di fabbrica e i brevetti d'invenzione; abbraccia insomma tutti gli oggetti della proprietà intellettuale ed industriale". (STOLFI, Nicola, La Proprietà Intellettuale, vol. I, Editrice Torinese, 1915, p. 343)

${ }^{2}$ Em que pese a drástica cisão anteriormente feita pela doutrina entre propriedade industrial e direito autoral, hoje estes dois campos são tratados como espécies do gênero propriedade intelectual.

3 Luiz Guilherme Marinoni pondera que "somente as criações intelectuais tomadas em consideração pelo direito apresentam-se como bens intelectuais e, assim, como bens imateriais". (Marca Comercial, Direito de Invento, Direito Autoral etc. Impropriedade do Uso das Ações Possessória, Cominatória e Cautelar. Cabimento da Ação Inibitória, in Revista dos Tribunais, vol. 768, São Paulo: RT, 1999, p. 23).

${ }^{4}$ DI BLASI, Clésio Gabriel, A Propriedade Industrial, Rio de Janeiro: Guanabara Dois, 1982, p.6.

${ }^{5}$ Da Noção de Bens Imateriais, Disponível em 〈http://www.denisbarbosa.addr.com/136.doc >. Acesso em 15 mai. 2009.

${ }^{6}$ Art. 1.270. Se toda a matéria for alheia, e não se puder reduzir à forma precedente, será do especificador de boa-fé a espécie nova. (...) § 20 Em qualquer caso, inclusive o da pintura em relação à tela, da escultura, escritura e outro qualquer trabalho gráfico em relação à matéria-prima, a espécie nova será do especificador, se o seu valor exceder consideravelmente o da matériaprima.
} 
física ou já imaterial (a cultura, ou uma obra preexistente, ou o estado da técnica), é a adição de valor resultante de um trabalho do criador que constitui a obra ou invento" e este valor não deve ser necessariamente econômico ${ }^{7}$, ainda que o seja na maioria das hipóteses.

José Cretella Júnior, aclarando este aspecto da intelectualidade, dispõe que:

"Concretizando ou não o invento industrial em máquinas ou aparelhos, o objeto de propriedade industrial é o bem incorpóreo, o objeto ideal, a idéia, o que define o invento, naquilo que é passível de direito de propriedade industrial" ${ }^{\circ}$.

Assim, como resultado do esforço destas atividades intelectuais para a obtenção de uma dada obra, seja esta uma invenção, um quadro, ou um livro, o ordenamento jurídico apresenta uma proteção ao criador para que este possa auferir o conseguinte proveito econômico oriundo de sua criação.

Vale pontuar que a propriedade intelectual se divide em dois subsistemas $^{9}$ : direito autoral e propriedade industrial. O direito autoral abarca as obras literárias e artísticas, ao passo que a propriedade industrial engloba as patentes, as marcas, os desenhos industriais, os segredos industriais, como outros bens intelectuais de aplicação industrial.

Em ambos os subsistemas esteve presente a dificuldade de caracterização da relação criador/obra, bem como dos direitos oriundos de tal relação, o que acabou culminando, em que pese as divergências doutrinárias ${ }^{10}$, em ambos os casos, cada um com as suas especificidades,

\footnotetext{
${ }^{7} \mathrm{~A}$ invenção precisa ser útil, assim, João da Gama Cerqueira preleciona que "geralmente as invenções realizam um progresso e proporcionam vantagens de qualquer ordem, mas isto não é essencial ao seu conceito. Do mesmo modo, pouco importa o valor financeiro da invenção ou o proveito pecuniário que dela possa ser auferido em sua exploração. O que se exige é que a invenção dê um resultado útil em si." (Tratado da Propriedade Industrial, vol. I, Rio de Janeiro: Forense, 1982, p. 242).

${ }^{8}$ Comentários à Constituição Brasileira de 1988, vol. I, São Paulo: Forense Universitária, 1989, p. 405.

${ }^{9}$ GANDELMAN, Marisa, Poder e Conhecimento na Economia Global: O Regime Internacional da Propriedade Intelectual da sua Formação às Regras de Comércio Atuais, Rio de Janeiro: Civilização Brasileira, 2004, p. 78.

${ }^{10}$ A doutrina atual é pacífica ao entender o direito de autor e de inventor como um direito de propriedade, no entanto, é possível encontrar autores, como João Bardalho, que entendem de forma diversa. Bardalho, citado por José Cretella Júnior, assim dispõe em sua obra: "O invento é antes uma combinação do que verdadeiramente criação. Versa sobre elementos preexistentes, que fazem parte desse repositório de idéias e conhecimentos que o tempo e o progresso das nações têm acumulado e que não são suscetíveis de serem apropriados com uso exclusivo por quem quer que
} 
em um alargamento da concepção do conceito de propriedade ${ }^{11}$, de forma a abarcar estas situações peculiares.

No entanto, no que tange à propriedade da obra, na propriedade industrial o direito de propriedade é atribuído pelo Estado, nos termos dos requisitos legais; enquanto que na propriedade literária e artística, o direito já existe a partir da criação da obra, não necessitando de registro, comprovação de autoria ou do preenchimento de requisitos legais para que a proteção incida sobre o autor.

Feitas tais considerações, cumpre destacar que a propriedade intelectual, nos dias atuais, abandonou o pequeno grupo das pessoas e empresas interessadas em inovação, passando a ganhar uma dimensão político-econômica sem igual, já que hoje vigora a "primazia da informação dentro da dinâmica do mundo econômico, com a conseqüente prevalência do patrimônio intangível sobre o tangível" 12 , sendo crescentes os números de acordos multilaterais internacionais que versam sobre a matéria.

Dessa forma, agora, mais do que nunca, a discussão sobre a titularidade dos direitos oriundos da propriedade intelectual mostra a sua importância, pois havendo a consciência do bem intangível como instrumento gerador de riquezas ${ }^{13}$ e de poder político, as tensões se acirram entre os titulares destes direitos e a sociedade.

\footnotetext{
seja, constituindo antes um patrimônio comum (...)". (Comentários à Constituição Federal Brasileira,1902, pp. 331-332). Em entendimento diverso e atual, José Cretella Júnior afirma que "equivocou-se aqui o grande Bardalho, porque a propriedade intelectual é propriedade como outra qualquer. (...) Bens incorpóreos, como os corpóreos, são coisas suscetíveis de valor e, pois, podem ser objeto do direito de propriedade". (Op. cit., p.403).

${ }^{11}$ Neste sentido João da Gama Cerqueira conclui que "o direito de autor e de inventor é um direito privado patrimonial, de caráter real, constituindo uma propriedade móvel, em regra temporária e resolúvel, que tem por objeto uma coisa ou bem imaterial; denomina-se, por isso, propriedade imaterial, para indicar a natureza de seu objeto". (Op. cit., p. 242)

${ }^{12}$ CORREA, José Antonio B. L. Faria, A Proteção da Criação Intelectual conforme o Objeto da Obra, in Revista da ABPI, n. 64, mai/jun, Rio de Janeiro, 2003, p. 68.

13 "The importance of intangible assets is magnified by the fact that they are not restricted to the high technology sector, but are instead dominant in every well-run enterprise. A recent ranking of the fifty US companies with the largest intangible capital (...) contained not just 'new-economy' firms, such as Microsoft, Intel, America Online, and Cisco Systems, but also twenty-eight 'oldeconomy' companies such as General Electric, Wall-Mart, DuPont, Coca-Cola, and Alcoa. Examples of other non-tech companies with valuable intangibles are British Petroleum, Goldman Sachs, and Unilever. In today's economy, intangible assets are pervasive across virtually all business sectors and in every major industrial country". (HAND, John R. M.; LEV, Baruch,
} 
Mais delicada ainda será esta relação quando o detentor do direito de propriedade for um empregado, pois não apenas estará em voga a discussão entre sociedade e titular de direitos, como também uma relação, em desigualdade de forças $^{14}$, entre empregado inventor e empregador que deseja explorar economicamente o invento. Ou, o que é pior, algumas vezes, o empregador pode se sentir prejudicado face à novidade inventiva e, nestes casos, a desigualdade de forças poderá se mostrar ainda mais flagrante.

Neste sentido, vale citar o caso de Edwin Howard Armstrong, inventor do rádio FM. Anteriormente à sua descoberta, o rádio de consumo era o de amplitude modulada (AM), mas Armstrong descobriu que se este trabalhasse em uma "ampla faixa do espectro magnético, poderia oferecer uma incrível fidelidade ao som, com necessidade de potência do transmissor e estática muito menores" ${ }^{\prime 15}$, ou seja, em termos práticos, passou a ser possível ouvir o real som de um copo de água se enchendo, de um papel sendo amassado e rasgado, sem contar a qualidade do som das músicas, que passaram a poder ser ouvidas com extrema clareza.

No entanto, ao tempo de sua invenção revolucionária, Armstrong trabalhava para a RCA, a principal empresa de mercado de rádios AM. Quando Armstrong demonstrou para o presidente da RCA a sua invenção, este concluiu que àquela nova tecnologia iria competir frontalmente com a sua empresa, o que o fez se utilizar de toda a sua influência política e do seu aparato corporativo (escritório de vendas, jurídico, etc) para sufocar a nova tecnologia, ainda que esta fosse, em muito, superior.

\footnotetext{
Introduction and Overview, in Intangible Assets: Values, Measures, and Risks, New York: Oxford University Press, 2003, pp. 1-2).

${ }^{14}$ Como esclarece Vólia Bomfim Cassar: "o empregado não tem a mesma igualdade jurídica que o empregador, como acontece com os contratantes no Direito Civil. (...) No Direito do Trabalho há uma desigualdade natural, pois o capital possui toda a força do poder econômico. (...) $\mathrm{O}$ trabalhador já adentra na relação de emprego em desvantagem, seja porque é vulnerável economicamente, seja porque depende daquele emprego para sua sobrevivência (...)". (Direito do Trabalho, Niterói: Impetus, 2008, pp.182-183).

${ }^{15}$ Este caso específico é relatado, com uma riqueza maior de detalhes na obra Cultura Livre, de Lawrence Lessig, disponível para download no link: <http://www.rau-tu.unicamp.br/nourau/softwarelivre/document/?view=144>. Acesso em 15 mai. 2009.
} 
Armstrong acabou enfrentando a RCA, que acabou questionando as suas patentes, o que lhe rendeu uma disputa jurídica de seis anos, sem o recebimento dos royalties que lhe eram devidos. Por fim, quando as patentes expiraram, a RCA lhe ofereceu um acordo tão prejudicial, que este não pode arcar nem com os honorários dos advogados, o que o levou, ao final, a cometer suicídio.

Dessa forma, em que pese este exemplo concreto e dramático, é importante a discussão sobre os direitos inerentes ao inventor e quais os seus limites no âmbito do contrato de trabalho, e em face do interesse social; pois, por mais que se pense que as invenções ocorrem apenas nos laboratórios dotados de grande tecnologia, a história, em realidade, revela que " $70 \%$ das invenções atuais mais importantes são provenientes de inventores isolados" "16. Nestes termos, abarcando a evolução desta discussão, em termos doutrinários e jurisprudenciais, será este o foco do presente trabalho.

\subsection{O PATRIMÔNIO INTANGÍVEL DA EMPRESA E AS RELAÇÕES TRABALHISTAS:}

No contexto atual, os bens intangíveis, por possuírem crescente valor econômico, são considerados freqüentemente os mais importantes dos ativos das empresas e indústrias. Tal fator tem influenciado diretamente, por exemplo, no processo de vendas de empresas, tendo os ativos tangíveis perdido cada vez mais espaço para os ativos off-ballance ${ }^{17}$. Dessa forma, investir de forma a expandir o patrimônio intangível representa agregar mais valor a própria empresa ou indústria.

Assim, compreendendo os ditames desta nova dinâmica econômicosocial, os próprios Tribunais brasileiros têm percebido como os intangíveis agregam valor ao patrimônio empresarial. Neste sentido, pensando a

\footnotetext{
${ }^{16}$ DI BLASI, Clésio Gabriel, Op. cit., p.15.

${ }^{17}$ SOUZA, Ana Cristina França de, Avaliação de Propriedade Intelectual e Ativos Intangíveis, in Revista da ABPI, n. 39, São Paulo, pp. 9-14.
} 
questão trabalhista empregado inventor/empregador, confira-se acórdão, do Tribunal Regional do Trabalho da $14^{\mathrm{a}}$ Região ${ }^{18}$, que reconhece a importância econômica dos bens imateriais para o adequado funcionamento da empresa e o conseqüente pagamento de seus empregados, ao concordar com o reclamante que sustenta que:

"a segunda reclamada adquiriu a divisão de segurança do trabalho da empresa Pomp, antiga razão social da primeira reclamada, que representava mais de $70 \%$ do faturamento, maior parte da rentabilidade, incluindo marca, patentes, moldes, cadastro de clientes e demais bens que compunham o valor e a estabilidade da empresa no mercado de trabalho".

Concluindo, o relator, por sua vez, que:

"no caso, houve uma evidente alteração na estrutura jurídica da primeira reclamada, que afetou o seu patrimônio não-fungível (direitos de marcas, patentes, e moldes) reduzindo a sua importância no mercado e tornando temerária a situação de seus empregados (...)”. (grifos nossos)

O que acaba por justificar, no caso em tela, a responsabilização subsidiária da empresa adquirente, segunda reclamada, pelos créditos oriundos da demanda.

Nesta seara do despertar do interesse mercadológico para os ativos intangíveis, as empresas têm tido uma preocupação crescente em investir no ramo da inovação, pelos mais diversos motivos, dentre os quais se encontram: as tentativas de sobrevivência à realidade competitiva e de alcance de fatias maiores do mercado, nos ditames da lógica capitalista ${ }^{19}$. Nessa dinâmica, empregados são contratados com o escopo de desenvolver novas tecnologias para as empresas ou, os que acabam por inventar alguma

\footnotetext{
${ }^{18}$ TRT14, 6 ${ }^{\text {a }}$ T., RO n. 00067-2007-251-04-00-6, Rel. Juíza Convocada Iris Lima de Moraes, julg. 29.10.2008.

${ }^{19}$ Exemplos dessa crescente preocupação de investimento nos intangíveis são enumerados por Leonard Nakamura: "Gillette invested \$ 700 million to develop the Mach3 razor blade from 1990 to 1998. AOL/TimeWarner spent over $\$ 150$ million to bring J.K. Rowling's vision of 'Harry Potter and the Sorcerer's Stone' to the screen. These investment expenditures gave rise to economically valuable, legally recognized intangible assets, including copyrights (...) and patents (...) that give the investing firms the exclusive right for a certain period to sell the newly developed products. These assets can be extremely valuable. Pfizer sold over $\$ 1$ billion worth of Viagra in 1999 after its introduction in April of the previous year; 'Harry Potter' sold nearly $\$ 100$ million in movie-theater tickets its first weekend, and Gillette's Mach3 razor blade was the top seller in the United States by the end of 1998, having secured more than 10 per cent of the razor blade replacement market in less than a full year". (A Trillion Dollars a Year in Intangible Investment and The New Economy, in Intangible Assets: Values, Measures, and Risks, New York: Oxford University Press, 2003, p.19).
} 
tecnologia no âmbito da relação de trabalho, podem acabar por ter o seu invento explorado economicamente pela própria empresa empregadora.

\subsection{A PROTEÇÃO AO INVENTOR EM SEDE CONSTITUCIONAL:}

As invenções colaboram diretamente para um aumento do nível de vida da população e geram, em última análise, o desenvolvimento econômico do país e da humanidade. Mas, ao longo deste processo em busca da inovação, os gastos são dispendiosos e são envolvidas, muitas das vezes, grandes equipes especializadas, contratadas para tal fim. Dessa forma, não garantir um privilégio de exploração econômica, ao detentor do invento, representaria grande desestímulo à pesquisa e à inovação industrial, o que não estimularia a concorrência ${ }^{20}$, e, por conseguinte, não fomentaria o desenvolvimento econômico, e a geração de bem-estar social.

Neste sentido, dispõe Carvalho de Mendonça, de forma esclarecedora, que:

"o industrial ou técnico que, após meditados estudos, demoradas investigações e penosos sacrifícios, consegue inventar ou descobrir novos produtos industriais, novos meios ou a aplicação nova de meios conhecidos para obter um produto ou resultado industrial, ou melhorar a invenção de outros, presta relevante serviço à sociedade, concorrendo para o fomento da indústria, e tem o incontestável direito do fruto do seu labor." ${ }^{21}$

Com o escopo de assegurar essa fruição por parte do inventor, certos países atribuem proteção à propriedade industrial pelas próprias normas genéricas de proteção à propriedade. Assim, a proteção conferida à propriedade industrial, autonomamente, representaria apenas um reforço ou uma garantia maior ao exercício do direito do criador. Mas, a par das especificidades de cada ordenamento jurídico, pode-se afirmar que não existem privilégios perenes conferidos ao inventor, mas as suas prerrogativas são adstritas a um tempo estimado como justo e razoável para

\footnotetext{
${ }^{20}$ Em encontro a este entendimento dispõe Karin Grau-Kuntz que "a razão de reconhecimento e garantia do sistema de patentes reside na sua instrumentalidade concorrencial". (Direito de Patentes - Sobre a Interpretação do Artigo $5^{\circ}$, XXIX da Constituição Brasileira, in Revista da ABPI, n. 98, Rio de Janeiro: Garilli Gráfica, 2009, p. 47).

${ }^{21}$ Direito Comercial Brasileiro, vol. V, Rio de Janeiro: Bastos, 1938, p.111.
} 
que este extraía a fruição de todos os resultados da sua criação, e, após o decurso de tal lapso temporal, a patente é extinta, caindo o invento em domínio público.

No caso específico do ordenamento jurídico brasileiro, os direitos do inventor encontram a sua proteção autônoma assegurada já em sede constitucional. Nesta seara é preceituado pela Carta Magna de 1988, no inciso XXIX, do art. $5^{\circ}$, que:

"a lei assegurará aos autores de inventos industriais privilégio temporário para sua utilização, bem como proteção às criações industriais, à propriedade das marcas, aos nomes de empresas e a outros signos distintivos, tendo em vista o interesse social e o desenvolvimento tecnológico e econômico do País;”.

Assim, cumpridos os requisitos legais estipulados pela Lei $n^{\circ} 9.279$, de 14 de maio de 1996, que regula direitos e obrigações relativos à propriedade industrial, reconhece-se o privilégio. O órgão incumbido de tal tarefa é o Instituto Nacional da Propriedade Industrial (INPI), cujo ato administrativo de reconhecimento é meramente recognitivo ou declaratório $^{22}$, haja vista que o privilégio decorre da própria invenção desenvolvida pelo inventor, sendo passível de controle e revisão pelo Judiciário. Dessa forma, o INPI assegura a proteção ao inventor, ao "conferir segurança e certeza quanto à procedência da invenção"23, que, por sua vez, deverá ser utilizada, sob pena de perda do direito exclusivo de uso.

Por fim, o privilégio se naturaliza por intermédio da carta patente, que é um instrumento formal que vincula o nome do autor a sua invenção, tendo este direito ao uso exclusivo do objeto patenteado por tempo determinado $^{24}$, que no caso das patentes de invenção é de vinte anos, em contrapartida, no caso dos modelos de utilidades é de quinze anos (artigo 40 da Lei $\left.n^{\circ} 9.279 / 1996\right)$.

\footnotetext{
${ }^{22}$ Nas palavras de Gustavo José Ferreira Barbosa: "ao longo do tempo, a patente perdeu o caráter de privilégio, favor governamental, e passou a ser um direito previsto em lei, ao alcance de todos". (A Introdução no Nosso Ordenamento Jurídico do Requisito da Atividade Inventiva como Condição Legal para a Concessão de uma Patente de Invenção, in Revista Forense, vol. 339, Rio de Janeiro: Forense, 1997, p.89).

${ }^{23}$ BASTOS, Celso Ribeiro; MARTINS, Ives Gandra, Comentários à Constituição do Brasil, vol. II, São Paulo: Saraiva, 2001, p. 160.

${ }^{24} \mathrm{Com}$ tal formalização passa a vigorar a propriedade (com os direitos que lhe são inerentes), bem como o uso exclusivo erga omnes.
} 
Em contraposição à antiga idéia de justo prêmio $^{25}$ (previsto, por exemplo, na Constituição brasileira de 1946), a partir da Constituição de 1967, entra em cena o instrumento da desapropriação ${ }^{26}$, ou seja, ainda que o invento resulte da criatividade de seu autor ${ }^{27}$, o direito deste sobre àquela não será absoluto, mas, ele poderá ser expropriado pelo Estado, assim como qualquer bem o seria, se considerado de interesse social, de utilidade ou de necessidade pública.

Complementando o raciocínio acima exposto do sistema de patentes como fomentador do bem-estar social, cumpre apresentar segunda limitação ao direito do inventor, após a possibilidade de desapropriação. A proteção conferida não será livre e irrestrita, mas encontrará, além da limitação temporal para a fruição, limitações emanadas dos princípios norteadores do ordenamento jurídico, sob pena de levar à ruína o próprio sentido do sistema de patentes.

Nesta seara, não poderá o invento gerar efeitos prejudiciais à sociedade, assim como deverá o inventor, diante da instituição do monopólio instrumental, promover o uso social da propriedade ${ }^{28}$, nos ditames do inciso XXIX, do artigo $5^{\circ}$, in fine e do inciso III, do artigo 170, ambos do texto constitucional.

No que tange à vedação de geração de efeitos prejudiciais à sociedade, no âmbito da própria legislação ordinária, preceitua-se que não são patenteáveis as invenções "contrárias à moral, aos bons costumes e à segurança, à ordem e à saúde pública” (artigo 18, da Lei n. 9.729/1996). Ou seja, o reconhecimento e a manutenção dos direitos do inventor estão

\footnotetext{
${ }^{25} \mathrm{O}$ justo prêmio consistia na indenização paga ao inventor pelo Estado, quando este vulgarizava o invento; sendo pago o quantum nos ditames do valor do invento e dos gastos que se ornassem indispensáveis. Este instituto encontra a sua fundamentação no receio de que o inventor pudesse se valer do seu privilégio para obstar a utilização da nova tecnologia.

${ }^{26}$ No caso das Pessoas Jurídicas de Direito Público, o direito de adquirir patente está adstrito à União nos casos de desapropriação.

${ }^{27}$ CRETELLA JÚNIOR, José, Op. cit., p. 403.

${ }^{28}$ Dispondo sobre o uso dos direitos pelo inventor, Luiz Guilherme de A. V. Loureiro dispõe que "o uso abusivo desse direito, ou mesmo o não-uso (falta de exploração da patente e recusa em conceder licenças voluntárias), pode dar ensejo à uma intervenção do Estado que promoverá a licença obrigatória de sua patente (art. 68)". (A Lei de Propriedade Industrial Comentada, São Paulo: Lejus, 1999, pp.39-40)
} 
adstritos aos limites e aos valores da ordem pública, por mais que, sob uma primeira análise, pudesse este invento gerar algum nível de bem-estar social.

A título ilustrativo vale citar o exemplo, exposto por Karin Grau$\mathrm{Kuntz}^{29}$, da máquina de falsificar dinheiro. Por mais que dito invento possa estimular, em uma primeira análise, a concorrência, o que significaria, $a$ priori, um aumento do bem-estar geral sob a ótica econômica; certo é que, após uma análise mais atenta, nos depreenderíamos com toda a sorte de consequiências negativas oriundas de uma enxurrada de notas falsas, o que levaria a uma desestabilização do mercado, afrontando, por fim, o interesse público.

Dessa forma, o sistema de patentes encontra a sua efetividade no bojo do mercado, por intermédio do estímulo à concorrência, alcançando, nestes termos, a sua finalidade última, que é o bem-estar social; mas, para tanto, o interesse público deve ser invocado, sob pena de subversão de toda a estrutura.

\subsection{A PROTEÇÃO AO INVENTOR NA LEGISLAÇÃO ORDINÁRIA:}

Após a análise da proteção genérica conferida ao inventor pela Constituição Federal de 1988, cumpre analisar agora a legislação ordinária (Lei 9.278/1996) que garante a propriedade, com todos os eventuais direitos acessórios, ao inventor no que toca à sua invenção, por intermédio da cartapatente $^{30}$. É importante frisar que será esta qualidade de autor que garantirá o direito de obtenção da patente.

Em realidade, "o direito do inventor, realmente, nasce com a própria invenção ${ }^{31}$, podendo ele, a partir dessa data, dispor dela como bem

\footnotetext{
${ }^{29}$ Op. cit., p. 48.

${ }^{30}$ Art. $6^{\circ}$. Ao autor de invenção ou modelo de utilidade será assegurado o direito de obter a patente que lhe garanta a propriedade, nas condições estabelecidas nesta Lei.

${ }^{31}$ Reconhecendo a existência dos direitos inerentes ao inventor-empregado, o Tribunal Superior do Trabalho entendeu ser cabível o ressarcimento ao trabalhador mesmo em caso de ausência de carta-patente. Assim, nas palavras do ministro Delazen: "Diante da prova testemunhal e pericial colhida, no sentido da existência de lucro pelas empresas com a utilização dos inventos (quer em
} 
entender. Assim, seu direito existe antes de qualquer exploração, mas o direito à exclusividade desta, o direito de propriedade industrial, só aparece com o deferimento da patente" 32 , momento no qual é o interesse da comunidade que comanda a concessão dos privilégios.

Dessa forma, não incide a propriedade sobre o objeto da invenção, mas sobre o título e sobre o direito exclusivo de exploração da invenção por ele conferido. Assim, o inventor pode explorar pessoalmente a invenção; ou pode ceder os seus direitos, dispondo destes, renunciando-os, ou mediante contrato de licença ou de cessão de direitos. Também é possível a ocorrência de co-propriedade ou compropriedade, quando várias pessoas concorrem para a realização da invenção, podendo cada qual fruir o respectivo quantum que lhe couber; são as denominadas patentes coletivas ou comuns.

Já nos ditames do foco do presente trabalho, a invenção também pode ser realizada em função de um contrato de trabalho ou "de pesquisa". Por intermédio deste, uma pessoa pode contratar com outrem que conceba invenção por sua conta. No entanto, esta temática será abordada oportunamente no decorrer do trabalho.

Mas, por ora, já se depreende que a lei não limita o direito de obter patentes de invenção às pessoas físicas. Poderão, também, as pessoas jurídicas $^{33}$, de Direito Público ou Privado, requerê-las como proprietárias das invenções realizadas "por sua conta, por pessoas a seu serviço, ou das que adquirirem antes de pedido o privilégio. No primeiro caso, são sujeitos originários do direito, no segundo, sujeitos derivados" ${ }^{34}$.

mão de obra, tempo despendido, melhorias técnicas ou vantagens econômicas, bem como à medicina e segurança do trabalho), entendo que a falta de requisito formal (expedição de carta patente), não pode servir ao indeferimento da indenização". (in Revista Eletrônica do Tribunal Regional do Trabalho da $4^{a}$ Região, n. 32, 2006, pp. 65-66).

${ }^{32}$ STF, Trib. Pleno, RE n. 93679-RJ, Rel. Min. Moreira Alves, julg. 1.2.1984.

33 À exceção dos sindicatos que não podem exercer atividades econômicas, comerciais ou lucrativas.

${ }^{34}$ CERQUEIRA, João da Gama, Op. cit., p.251. 
Retomando a discussão acerca da caracterização ${ }^{35}$ da invenção na lei ordinária, voltemos as atenções para os requisitos essenciais à patenteabilidade, dispostos no artigo $8^{\circ}$, da Lei 9.278/1996: “é patenteável a invenção que atenda aos requisitos de novidade, atividade inventiva e aplicação industrial". Assim, segue abaixo exposição que visa coadunar os termos utilizados pela lei, de forma a cumprir os requisitos necessários à patenteabilidade, pois na ausência de qualquer destes a patente não poderá ser concedida.

O primeiro elemento a ser analisado, pelo INPI, é o da novidade, que vem disposto nos artigos 11 e 12 da Lei 9.279/1996 $6^{36}$. Tudo aquilo que previamente não existia será novo. Este requisito, no entanto, deverá ser concebido analisando o corpo de conhecimento em âmbito mundial, e não apenas dentro de determinado país. Este corpo de conhecimento a ser levado em conta, para extrair o critério da novidade, é denominado de estado da técnica, ou seja, deverá o inventor agregar algo novo ao conhecimento da humanidade.

Para a aferição prática deste critério, o INPI realiza pesquisa ao acervo de documentos contidos no seu Banco de Patentes; havendo ainda a possibilidade de quaisquer interessados apresentarem subsídios a tal exame $^{37}$, ou o INPI poderá exigir do requerente que apresente "objeções,

\footnotetext{
${ }^{35}$ A lei não define precisamente o que é invenção, mas elenca o que não pode ser concebido como invenção.

36 "Art. 11. A invenção e o modelo de utilidade são considerados novos quando não compreendidos no estado da técnica. $\S 1^{\circ} \mathrm{O}$ estado da técnica é constituído por tudo aquilo tornado acessível ao público antes da data de depósito do pedido de patente, por descrição escrita ou oral, por uso ou qualquer outro meio, no Brasil ou no exterior, ressalvado o disposto nos arts. 12, $16 \mathrm{e}$ 17. $\S 2^{\circ}$ Para fins de aferição da novidade, o conteúdo completo de pedido depositado no Brasil, e ainda não publicado, será considerado estado da técnica a partir da data de depósito, ou da prioridade reivindicada, desde que venha a ser publicado, mesmo que subseqüentemente. $\S 3^{\circ} \mathrm{O}$ disposto no parágrafo anterior será aplicado ao pedido internacional de patente depositado segundo tratado ou convenção em vigor no Brasil, desde que haja processamento nacional. Art. 12. Não será considerada como estado da técnica a divulgação de invenção ou modelo de utilidade, quando ocorrida durante os 12 (doze) meses que precederem a data de depósito ou a da prioridade do pedido de patente, se promovida: I - pelo inventor; II - pelo Instituto Nacional da Propriedade Industrial - INPI, através de publicação oficial do pedido de patente depositado sem o consentimento do inventor, baseado em informações deste obtidas ou em decorrência de atos por ele realizados; ou III - por terceiros, com base em informações obtidas direta ou indiretamente do inventor ou em decorrência de atos por este realizados".

${ }^{37}$ Art. 31. Publicado o pedido de patente e até o final do exame, será facultada a apresentação, pelos interessados, de documentos e informações para subsidiarem o exame.
} 
buscas de anterioridade e resultados de exame para concessão de pedido correspondente em outros países" 38 .

$\mathrm{O}$ segundo elemento essencial à patenteabilidade, que vem, pela primeira vez, explicitado na lei, é a atividade inventiva, cuja conceituação está disposta no artigo 13, da Lei 9.279/1996, que assim prescreve: "A invenção será dotada de atividade inventiva sempre que, para um técnico no assunto, não decorra de maneira evidente ou óbvia do estado da técnica".

Este requisito, já de há muito tempo, reconhecido pela doutrina e aplicado pelo INPI, está fundamentado na própria natureza do direito do inventor, ou seja, o Estado só concede o monopólio porque considera que tal invento trará grande benefício à sociedade, em especial quando cair em domínio público. Assim, não faria sentido uma ingerência estatal tão abrupta, se a "contribuição" trazida à baila já fosse de conhecimento geral; o que representaria verdadeira desvirtuação ao sistema de patentes e, em última análise, ato de grande nocividade à sociedade.

Para a melhor compreensão do conceito de atividade inventiva, fazse necessário a realização da distinção terminológica de invenção ${ }^{39}$, em face do conceito de descoberta, haja vista que a invenção, tal qual visto, é passível de patenteabilidade, ao passo que a descoberta não o é (artigo 10, I, da Lei 9.279/1996).

A invenção, nos ditames do acórdão da $1^{\text {a }}$ Turma, do Tribunal Regional do Trabalho da $3^{\text {a }}$ Região:

"na técnica jurídica, é assimilável como a ação de achar o que estava oculto. É a criação de coisa nova, no sentido comercial, constituindo-se em propriedade do inventor, que o torna exclusivo no direito de exploração mercadológica, aí, sim, mediante a concessão de patente. (...) A descoberta, por outro lado, envolve a coisa encontrada por acaso. Revela apenas o que não se conhecia"40.

Pontes de Miranda é preciso ao dizer que:

\footnotetext{
${ }^{38}$ Artigo 34, I, da Lei 9.279/1996.

39 As definições de invenção, na doutrina, são eivadas de grande controvérsia, dessa forma, é possível vislumbrar o posicionamento da escola francesa que enquadra a invenção dentro de um conceito jurídico, em contrapartida, a escola alemã possui um enfoque técnico-econômico. Dessa forma, tendo em vista que a lei, com muita propriedade, não define o que vem a ser invenção, será abordado no presente trabalho as aplicações da lei, sem pretensões de abordagem deste amplo campo teórico.

${ }^{40}$ TRT3, 1ª T., RO n. 18952/98, Rel. Des. Emília Facchini, julg. 16.8.1999.
} 
“(...) a engenhosidade [na invenção] ainda que mínima, há de existir (...). O que importa é que a atividade inventiva ultrapasse o que o técnico da especialidade podia, tal como estava a técnica, achar. $\mathrm{O}$ que todos os técnicos da especialidade, no momento podiam achar não é invenção (...). Porque tal achado estaria dentro da técnica do momento, sem qualquer quid novum $" 41$.

Dessa forma, o que diz ter inventado o que qualquer técnico da especialidade acharia, em realidade, faz descoberta; e não desenvolve invenção. Ou ainda, pode ter ocorrido em construção ${ }^{42}$, em razão de habilidade técnica, sem ter ocorrido propriamente em invenção ou descoberta.

Em complementação à distinção acima, Paolo Greco e Paolo Vercellone $^{43}$ atribuem à descoberta o reconhecimento ou a revelação de algo novo real antes ignorado, como, por exemplo, a descoberta de uma lei natural do mundo físico, todavia, tal descoberta, ao contrário da invenção, que promove uma inovação, não acarretará uma mudança direta no estado anterior das coisas.

Neste mesmo sentido, João da Gama Cerqueira ensina que:

"a invenção, de modo geral, consiste na criação de uma coisa até então inexistente; a descoberta é a revelação de uma coisa existente na Natureza. (...) A invenção (...) apresenta-se como a solução de um problema técnico, que visa à satisfação de fins determinados, de necessidades de ordem prática; a descoberta, ao contrário, (...) apenas aumenta a soma dos conhecimentos do homem sobre o mundo físico" ${ }^{44}$.

Feitas estas primeiras conceituações, é importante dizer que a atividade inventiva é elemento imprescindível no âmbito do sistema legal de patentes, haja vista que, sem o elemento contributivo da inovação, não faria sentido uma ingerência do Estado no mercado, com o escopo de

\footnotetext{
${ }^{41}$ Comentários à Constituição de 1967, Tomo V, São Paulo: Revista dos Tribunais, 1970, p. 551.

42 João da Gama Cerqueira, citando Bonnet, faz distinção entre invenção e construção. Nos ditames dessa explicação é possível extrair que a invenção sempre deve ter, ao fim, um resultado, ou um efeito técnico, imprevisto. A construção, em contrapartida, em que pese ser dotada de inovação, não excede à prática normal; sendo uma mera realização técnica de uma idéia criadora. Como exemplo, o doutrinador cita a inovação consistente na substituição de um material por outro; se o resultado decorrer necessariamente da diferença do material empregado, trata-se de construção; no entanto, se resultar em um efeito técnico peculiar, imprevisto, que não configure conseqüência lógica, configurada está a invenção. (Op. cit., pp. 235-237)

${ }^{43}$ Le invenzioni e i modelli industrialli, Torino: UTET, 1968, p.89.

${ }^{44}$ Op. cit., p. 222.
} 
instituição de um monopólio instrumental ${ }^{45}$, para proteção de uma criação que não constitua "um mínimo de contribuição ao conhecimento comum"46. A invenção se revela, em um primeiro plano, na inovação realizada; e, em segundo lugar, na originalidade da concepção do inventor, ou seja, no fato de este ter feito uso de suas faculdades inventivas.

Assim, levando em conta, não apenas o explicitado na legislação ordinária, como também o próprio artigo $5^{\circ}$, XXIX, da Constituição Federal (supracitado), é possível depreendermos que os requisitos de razoabilidade e proporcionalidade devem se fazer presentes para a instituição do privilégio, haja vista que não merecem proteção quaisquer alterações no estado da arte, mas sim, àquelas que constituam uma invenção significativa, que represente um substancial avanço frente ao já existente ${ }^{47}$.

Diante deste debate sobre invenção, esclarecedor é o acórdão da Terceira Turma, do Tribunal Regional do Trabalho da Terceira Região, ao dispor:

"Invenção. Onde penso estar havendo um grande equívoco, com confusão entre idéia e invenção ou invento, estes nos sentidos jurídico e técnico do termo que se lhe quer emprestar aqui. (...) chegando ao invento em sentido estrito aqui examinado, da criação original de algo novo, diferente e diverso de tudo que já existiu e que sirva para uma nova função ou utilidade, inexistente e impensada antes, gerando novidade, progresso e evolução tecnológica. O que, d.v., nada vejo aqui com (sic) a simples e singela idéia e não invenção de se amarrar o telefone público com um fio de aço para não ser furtado por vândalos. O que (sic) amarrar objetos para desestimular ou dificultar o furto é tão velho que se perde na memória dos tempos. (...) a lei somente assegura direitos de invenção a quem produza um invento que atenda aos requisitos de novidade,

\footnotetext{
${ }^{45}$ Nas palavras de Denis Borges Barbosa: "É preciso não só que haja novidade, mas também que a eficácia e a importância econômica dessa nova técnica seja discernível, de forma que se promova não apenas mínimos aumentos incrementais da tecnologia e sim algo que seja tão grandioso que justifique a criação de um monopólio instrumental". ( $O$ Comércio Internacional, $O$ Desenvolvimento Econômico e Social e Seus Reflexos na Ordem Internacional da Propriedade Intelectual, in Patrícia Luciane de Carvalho (Org.), Propriedade Intelectual: Estudos em Honra à Professora Maristela Basso, Curitiba: Juruá, 2005, pp. 17-39).

${ }^{46} \mathrm{O}$ que Denis Borges Barbosa denomina contributo mínimo, ou seja, é necessária "uma margem mínima de contribuição social além do simples investimento, dificuldade ou esforço". (Atividade Inventiva: Objetividade do Exame, in A Propriedade Intelectual no Século XXI - Estudos de Direito, Rio de Janeiro: Lumen Juris, 2009, p. 246).

${ }^{47}$ Preocupação presente inclusive em instrumentos de Direito Internacional, como é o caso do TRIPs, que dispõe em seu artigo $7^{\circ}$ : "A proteção e a aplicação de normas de proteção dos direitos de propriedade intelectual devem contribuir para a promoção da inovação tecnológica e para a transferência e difusão de tecnologia, em benefício mútuo de produtores e usuários de conhecimento tecnológico e de uma forma conducente ao bem-estar social e econômico e a um equilíbrio de direitos e obrigações".
} 
originalidade ou traga melhoria de uso de algo que já exista. O que não é o caso presente. (...) o A. informa nunca ter requerido a "patente" do seu "invento" no INPI (o que, seguramente, lhe seria negado, pois o ato de amarrar um bem para dificultar o roubo jamais seria patenteado) ${ }^{\prime 48}$. (grifos nossos)

Assim, diante da falta de novidade e atividade inventiva cabe ao Instituto Nacional da Propriedade Industrial (INPI) recusar o pedido, mas é importante frisar que esta análise será objetiva, ou seja, não se adentrará em questão subjetiva relativa à atividade criativa do inventor, ao seu esforço pessoal, ou ao quantum que se investiu para atingir o dado resultado. Como visto, o processo administrativo é vinculado, não cabendo, portanto, manifestações quanto à conveniência ou oportunidade do invento, assim, a análise da atividade inventiva se focará na contribuição objetiva da criação em face do conhecimento já existente, ou seja, deverá o invento contribuir para o avanço do estado da arte ${ }^{49}$.

Após a conceituação doutrinária do segundo requisito essencial à patenteabilidade, resta a análise do terceiro e último requisito, qual seja, a suscetibilidade de aplicação industrial do invento, cuja conceituação vem disposta no artigo 15, da Lei 9.279/96, que assim prescreve: “A invenção e o modelo de utilidade são considerados suscetíveis de aplicação industrial quando possam ser utilizados ou produzidos em qualquer tipo de indústria".

Este requisito remonta aos primórdios do incentivo à indústria, já que se vislumbrou que esta trazia melhoramentos ao padrão de vida da sociedade. Dessa forma, a expressão "aplicação industrial" deve ser

\footnotetext{
${ }^{48}$ RO n. 00812-2002-023-03-00-2, Rel. Des. Paulo Araújo, julg. 16.7.2003. Ainda no bojo desta discussão, reforça o entendimento a $2^{\mathrm{a}}$ Turma, do Tribunal Regional do Trabalho da Décima Região, ao preceituar que "a invenção exige a criação de objeto que observe os requisitos da novidade, para aplicação industrial, assim imprescindível produto novo ou resultado novo. (...) No caso, o empregado apenas dirigia sua criatividade dentro das técnicas conhecidas com resultados esperados como folders, convites, catálogos, informativos ilustrados e cartazes trazidos ao processo, pelo que se revela teratológica a possibilidade de patenteabilidade dessas criações vislumbradas pela parte". (TRT10, $2^{\mathrm{a}}$ T., RO n. 00056-2007-007-10-00-9, Rel. Des. Alexandre Nery de Oliveira, julg. 30.4.2008)

49 " $\mathrm{O}$ facto de inventar, sendo facto jurídico, gera, para o inventor, o poder jurídico de requerer a respectiva patente de invenção. Requerida a patenteação, vale dizer, exercido o poder jurídico de requerer, exercício que é facto jurídico, nasce, então, ao requerente, inventor, o direito subjetivo a que o Estado, devedor, preste ao inventor, requerente, acto, positivo ou negativo, de exame prévio. Verificará se o invento é novo e útil." (STF, RE n. 93679-RJ, Trib. Pleno, Rel. Min. Moreira Alves, julg. 1.2.1984).
} 
compreendida em uma acepção mais ampla, como exposto pela Convenção de Paris, que assim dispõe em seu artigo 1.3:

"A propriedade industrial entende-se na mais ampla acepção e aplica-se não só a indústria e ao comércio propriamente ditos, mas também às indústrias agrícolas e extrativas e a todos os produtos ou naturais, por exemplo: vinhos, cereais, tabaco em folha, frutas, animais, minérios, águas minerais, cervejas, flores, farinhas".

Portanto, o que se buscou de fato excluir da patenteabilidade, por intermédio deste terceiro critério, foram as criações de cunho intelectual, como as residentes no domínio das artes, que, por não serem técnicas, não têm aplicação industrial.

Nestes termos, o invento industrial será "a criação do ser humano que pode ser utilizada com êxito ou eficiência pela indústria, em virtude da novidade que a caracteriza" ${ }^{, 50}$; consistindo a invenção, portanto, na aplicação de uma dada descoberta para a consecução de um fim, sendo, dessa forma útil, já que soluciona um problema de ordem técnica.

\subsection{O MODELO DE UTILIDADE PATENTEÁVEL:}

São passíveis de patenteabilidade não apenas as invenções, como também os modelos de utilidade, que são definidos pelo artigo $9^{\circ}$, da Lei 9.279/1996, que assim dispõe:

"É patenteável como modelo de utilidade o objeto de uso prático, ou parte deste, suscetível de aplicação industrial, que apresente nova forma ou disposição, envolvendo ato inventivo, que resulte em melhoria funcional no seu uso ou em sua fabricação".

Os modelos de utilidade são novidades industriais de menor importância que as invenções, o que os leva a serem conhecidos como patentes de segunda classe. Por tal motivo, na legislação brasileira, em contraposição às patentes de invenção que vigoram por vinte anos, as de

${ }^{50}$ CRETELLA JÚNIOR, José, Op. cit., p. 405. 
modelo de utilidade somente dispõem de quinze anos de monopólio exclusivo, contados da data de depósito ${ }^{51}$.

Segundo se depreende de sua conceituação legal:

"o modelo de utilidade é um objeto que possui uma forma tridimensional, um corpo, uma estrutura plástica que o diferencia de seus similares e que lhe confere um caráter de novidade e que lhe possibilita um melhor uso ou facilita sua produção. Seu aspecto exterior deve lhe conferir uma fisionomia própria e nova"52.

Assim, esta inovação, tal qual na patente de invenção, também deverá ser dotada de atividade inventiva, para que esta nova aparência conferida ao produto, que o distingue dos demais, possibilite uma melhor utilização ou aplicação industrial deste, sob pena de possuir um simples caráter ornamental, o que lhe conferiria proteção, não a título de patente, mas a título de desenho industrial.

No entanto, é importante observar que o elemento da atividade inventiva presente nos modelos de utilidade não se dará exatamente nos moldes da atividade inventiva das patentes de invenção, haja vista que estas últimas representam nível mais elevado de invenção. Nestes termos, a nomenclatura especializada define os modelos de utilidade como inventos, e não como invenção.

Para sanar eventuais confusões entre o desenho industrial e o modelo de utilidade é importante estabelecer distinção entre o caráter simplesmente ornamental, ou design, da criação que se destina a um resultado industrial ou prático. Caso o resultado alcançado seja passível de ser alcançado por forma diversa, estar-se-á diante de forma dissociável do efeito técnico, sendo, portanto, desenho industrial. No entanto, se o resultado industrial somente puder ser obtido por intermédio de única forma, indissociável desta será o efeito técnico perseguido, o que lhe renderá a proteção do sistema de patentes, por tratar-se de modelo de utilidade.

\footnotetext{
${ }^{51}$ É o que dispõe o artigo 40, da Lei 9.279/96: “Art. 40. A patente de invenção vigorará pelo prazo de 20 (vinte) anos e a de modelo de utilidade pelo prazo 15 (quinze) anos contados da data de depósito".

${ }^{52}$ LOUREIRO, Luiz Guilherme de A.V., Op. cit., p. 46.
} 
Na seara trabalhista é possível encontrar julgados que envolvam a disputa de titularidade, entre empregado e empregadores, não apenas em razão das patentes de invenção, como também, em razão das patentes de modelo de utilidade; por tais motivos faz-se necessária a distinção doutrinária acima assinalada. 


\section{ALGUMAS QUESTÕES ENVOLVENDO O EMPREGADO INVENTOR:}

\subsection{A RELAÇÃO EMPREGADOR / EMPREGADO INVENTOR:}

Em que pese a assertiva geral de que a invenção pertence ao autor (como anteriormente abordado), há situações em que ela, por se exteriorizar e ganhar autonomia em relação ao seu criador, acaba por passar para a propriedade de outrem (por intermédio, por exemplo, da cessão de invenções futuras ${ }^{53}$ ), que, nos termos do presente trabalho, será o empregador.

No caso dos inventores autônomos, que não dependam do cessionário e que trabalhem livremente, não reside grande dificuldade de entendimento, haja vista que, de acordo com as mútuas estipulações pelas partes, celebrar-se-á o contrato de cessão de invenções futuras; cabendo, posteriormente, ao cessionário obter a respectiva patente ${ }^{54}$. Porém, a complexidade econômica e jurídica ganha espaço no caso de invenções ou inventos desenvolvidos pelos inventores salariados, ou seja, que realizam a atividade inventiva no bojo de um contrato de trabalho, ou, ainda, numa relação de emprego.

Em sua memorável obra, João da Gama Cerqueira conceitua os inventores salariados, em seu sentido mais amplo, que acaba por abranger:

"não só os inventores propriamente ditos, que contratam os seus serviços para trabalhar em pesquisas relativas a novas invenções, como também os empregados de qualquer categoria que eventualmente se tornem autores de qualquer invenção, desde os empregados superiores, que ocupam cargos de direção, como engenheiros, técnicos, cientistas, chefes de laboratório, etc., até os simples operários. O que importa, no caso, é a situação de dependência e subordinação que liga o autor da invenção ao empregador" ${ }^{\text {" }}$.

\footnotetext{
${ }^{53}$ A cessão de invenções futuras consiste na cessão antecipada, por parte do inventor, da propriedade das invenções que porventura realizar, em prol do cessionário. Trata-se de aquisição da propriedade a título derivado, motivo pelo qual não há violação ao princípio da propriedade do inventor.

${ }^{54}$ É importante assinalar que os efeitos do contrato limitam-se aos direitos patrimoniais adstritos ao invento ou invenção, pois ao inventor sempre caberá o direito moral à paternidade da invenção, ou seja, tem o inventor o direito de ser reconhecido como o autor de sua obra, haja vista que este direito é inalienável. Vale salientar, no entanto, que a nova lei assegura ao inventor o direito ao anonimato, ou seja, em respeito à sua liberdade de expressão e à sua privacidade, ele pode requerer a não divulgação de sua nomeação. No entanto, este anonimato em nada altera o direito subjetivo dos empregados inventores frente aos respectivos empregadores.

${ }^{55}$ Op. cit., p. 257.
} 
É justamente em razão desta dependência e subordinação que a discussão, sobre os inventores salariados, ganha relevo; principalmente diante da ausência de um contrato ou de disposições explícitas sobre as invenções.

$\mathrm{O}$ antagonismo de interesses entre o empregado e o empregador ${ }^{56}$ no caso concreto é fato notório, pois se vislumbra o interesse de ambos em fruir economicamente o invento ou invenção. Assim, se por um lado o direito à invenção ou invento deve sempre recair exclusivamente sobre o seu autor; por outro lado, o empregador tem direito ao resultado do trabalho do empregado, pois para realizá-la, este geralmente utiliza-se dos meios materiais do empregador, do auxílio de outros colegas de trabalho (ou seja, do capital intelectual da empresa), ou do conhecimento adquirido na realização do seu trabalho cotidiano.

Dessa forma, na visão do empregado, o patrão não passa de um contrafator; em contrapartida, sob a ótica do empregador, invocando os deveres de lealdade e diligência do empregado, a invenção desenvolvida faz parte das atividades normais deste, no curso do trabalho, ele tendo ou não sido pago para tanto.

Essa disputa que parece cingir-se unicamente a um vínculo empregatício específico, em realidade, tem uma proporção maior. A proteção dos interesses e dos direitos do empregado, em ditos casos, tem o papel de incentivá-lo a inventar mais, bem como de fazê-lo contar ao seu empregador quando da ocorrência de nova invenção.

As atividades de pesquisa que se desenvolvem dentro das organizações, em realidade, estão mais focadas na inovação (aperfeiçoamento e desenvolvimento das invenções com fulcro nas necessidades mercadológicas), do que na invenção propriamente dita. Mesmo em lugares de avançada tecnologia, são os indivíduos que inventam, pois a criatividade é inata a determinados indivíduos, sendo, portanto, uma atividade essencialmente individual, mesmo nas

\footnotetext{
56 O presente trabalho focará na relação de emprego e em suas divergências doutrinárias e jurisprudenciais; fazendo apenas, quando necessário, a título de comparação, remissão às invenções ou inventos desenvolvidos no âmbito do contrato de trabalho, mas sem o escopo de aprofundamento em dita temática.
} 
grandes organizações. Assim, cabe aos empregadores respeitar os direitos destes inventores, pois, em última análise, a sociedade de modo geral se beneficia com o ato inventivo. E, caso ele não o faça, caberá à lei oferecer a proteção devida a este inventor.

A proteção aos empregados inventores é matéria de ordem pública, com respaldo nos artigos 170 e 193 da Constituição Federal. Assim, a ordem econômica deve buscar seu fundamento "na valorização do trabalho humano" e “o primado do trabalho" é base da Ordem Social. Dessa forma, o desenvolvimento econômico e tecnológico deve se coadunar com a valorização do trabalho; devendo haver, portanto, equilíbrio entre o capital e o trabalho.

\subsection{DO PAGAMENTO DEVIDO AO EMPREGADO:}

Antes de ingressar na temática propriamente dita das modalidades de invenção ou inventos, no bojo da relação empregatícia, cumpre tecer considerações acerca das parcelas com natureza de direito intelectual que eventualmente sejam devidas ao empregado, pelo empregador.

Estas parcelas não possuem natureza jurídica salarial, mas sim natureza jurídica específica e distinta, assim, elas não se comunicam com o salário do empregado, pois elas "derivam de um direito específico adquirido pelo trabalhador ao longo do contrato, com estrutura, dinâmica e fundamento jurídicos próprios". 57

Neste sentido, dispondo sobre a natureza desse crédito, o Tribunal Regional do Trabalho da $12^{\mathrm{a}}$ Região assim dispôs:

“(...) a disputa entre as partes não trava, a toda evidência, a propósito de prestação de cunho trabalhista, no sentido de que derive diretamente de obrigação do contrato de emprego. Logo, não se cogita aqui propriamente de crédito trabalhista"58.

As classificações doutrinárias e os casos concretos trabalhados pela jurisprudência serão pontualmente abordados. No entanto, por agora, faz-se

\footnotetext{
${ }^{57}$ DELGADO, Maurício Godinho, Op. cit., p. 98.

${ }^{58}$ RO n. 00787-2006-008-12-00-9, 3ª T., Rel. Juíza Lília Leonor Abreu, julg. 24. 9.2007.
} 
necessária uma breve abordagem panorâmica sobre os diferentes cenários que podem se desdobrar da invenção ou invento desenvolvido pelo empregado, para que seja possível a compreensão da natureza do pagamento devido (ou não) ao empregado.

Caso o empregador não possua direitos sobre a invenção ou invento realizado pelo empregado, este poderá comercializar a sua obra livremente, inclusive com o próprio empregador, lhe sendo devido, em contrapartida, o pagamento de royalties. Neste caso, a pactuação entre empregador e empregado é descolada da relação empregatícia; sendo, portanto, inconcebível a idéia de que tais royalties tenham natureza salarial.

A contrario sensu, se for o empregador o único titular do invento ou invenção; não serão devidos royalties ao empregado em razão da comercialização da patente pelo empregador. Mas, há quem pondere que, mesmo em tais casos, se houver flagrante desproporcionalidade entre a remuneração do empregado e os resultados econômicos auferidos pelo empregador, ao primeiro será devida alguma participação nos lucros da invenção ou invento. Nesta hipótese, com fulcro no artigo $218, \S 4^{\circ}$, do texto constitucional ${ }^{59}$, João de Lima Teixeira Filho entende:

"ser indispensável que o empregador assegure ao autor da inovação uma participação a ser avençada, que tome por base o ganho que o empregador passou a ter com o produto da criatividade do seu trabalhador. Esta participação, que pode ser representada por um único pagamento ou parcelas mensais, não se incorpora ao salário do trabalhador, nem sobre ela incidem encargos sociais. A Constituição bem andou ao dizer que essa participação é 'desvinculada do salário'. Com isso, evita-se o receio de que a concessão se torne irreversível, onerosa em função dos encargos sociais e inibidora do processo de busca permanente por novos aperfeiçoamentos"

Em consonância com tal entendimento é disposto pelo artigo 89, da Lei n.

9.279/96 que:

"O empregador, titular da patente, poderá conceder ao empregado, autor de invento ou aperfeiçoamento, participação nos ganhos econômicos resultantes da exploração da patente, mediante negociação com o interessado ou conforme disposto em norma da

\footnotetext{
59 “A lei apoiará e estimulará as empresas que invistam em pesquisa, criação de tecnologia adequada ao País, formação e aperfeiçoamento de seus recursos humanos e que pratiquem sistemas de remuneração que assegurem ao empregado, desvinculada do salário, participação nos ganhos econômicos resultantes da produtividade de seu trabalho". (grifos nossos)

${ }^{60}$ Instituições de Direito do Trabalho, vol. I, São Paulo: LTr, 2005, p.261.
} 
empresa. Parágrafo único. A participação referida neste artigo não se incorpora, a qualquer título, ao salário do empregado".

Tal participação, ainda no entendimento de João de Lima Teixeira Filho, "não se confunde com os royalties que ele possa ter quando titular da patente de invenção que esteja sendo explorada" ${ }^{\circ 1}$.

Da mesma forma, o autor também entende que se o invento ou invenção é apenas utilizado no âmbito do estabelecimento, não caberão tampouco royalties, já que não há produção de renda pela patente. Assim, somente caberá uma participação pela utilização interna do invento ou invenção, que poderá tomar por base, para tanto, o ganho econômico agregado ao processo produtivo.

Em que pese as importantes ponderações feitas pelo autor, a doutrina e a jurisprudência tendem a utilizar a palavra royalties indiscriminadamente a todos os casos em que seja devido o pagamento ao empregado, pelos ganhos econômicos resultantes, para o empregador, da exploração da patente.

\subsection{DOS DANOS MORAIS DEVIDOS AO EMPREGADO:}

Os pleitos ajuizados, na Justiça do Trabalho, pelos empregados requerendo o pagamento de indenização pela fruição econômica do seu invento ou invenção, vêm, quase que na totalidade dos casos, cumulados com pedidos de indenização por danos morais.

Na conceituação dos danos morais trabalhistas, Alexandre Agra Belmonte explicita que estes são:

"ofensas aos atributos físicos, valorativos e psíquicos ou intelectuais decorrentes da relação de trabalho, suscetíveis de gerar padecimentos sentimentais ou ainda como decorrência do uso não autorizado da imagem ou da violação do bom nome da pessoa jurídica e, finalmente, os causados aos valores culturais de certa comunidade" ${ }^{" 62}$.

$\mathrm{Ou}$ seja, as ofensas aos direitos intelectuais do empregado, pelo empregador, podem ensejar a indenização a título de danos morais. Tal como abordado anteriormente, o inventor possui, por exemplo, o direito moral,

\footnotetext{
${ }^{61}$ Op. cit., p.261.

62 Danos Morais no Direito do Trabalho, Rio de Janeiro: Renovar, 2007, p.94.
} 
inalienável, de ser reconhecido como o autor de sua obra. Assim, mesmo que os direitos sobre a exploração da patente pertençam exclusivamente ao empregador, não poderá este desvincular o empregado de sua autoria intelectual, sob pena de ensejar o pagamento de danos morais ao empregado; o que não ocorreu no caso que se segue:

"Não cabe falar em dano moral, uma vez que não se vislumbra qualquer ofensa aos direitos da personalidade do autor, que não esteja reparada pela indenização acima fixada. Note-se que esse pedido da inicial embasa-se na alegação de que a reclamada não teria divulgado a autoria do reclamante sobre essa invenção, o que, no entanto, é afastado pelo próprio fato de que todas as testemunhas por ele trazidas sabiam dessa autoria" ${ }^{, 63}$.

Explicando os requisitos necessários para ensejar a reparação por danos morais e afastando a sua aplicação ao caso concreto, o TRT, da $13^{\text {a }}$ Região, assim dispôs:

"Para configuração do dano ensejador de reparação pecuniária, faz-se necessária a conjugação de vários requisitos, a saber: dano sofrido pelo empregado, erro de conduta do empregador, por dolo ou culpa (ato ilícito), e relação de causalidade entre a ação antijurídica e o dano causado. Não se trata de imputar responsabilidade objetiva ao empregador, mas aferir se o ente patronal, dolosamente ou por negligência, imprudência ou imperícia contribuiu para as sequielas sofridas pelo empregado (...). O mero sentimento de frustração pela não-utilização de seu pretenso invento pela empresa não caracteriza dano apto a conferir ao autor nenhuma indenização a título de danos morais, mormente quando não surte efeitos capazes de lhe afetar o lado psicológico, atingindolhe a esfera íntima e valorativa. Some-se a isso o fato de que não se pode imputar à empresa a prática de nenhum ato contrário à lei, o que afasta, de vez, a pretensão à reparação advinda de dano moral" ${ }^{\prime 64}$.

A aferição dos danos morais, bem como de seu valor indenizatório, trazem grandes dificuldades ao magistrado, haja vista que o dano é não-patrimonial, o que "reduz a possibilidade de aplicar-se um critério de pleno objetivismo na aferição da ocorrência efetiva do tipo constitucional (isto é, o efetivo prejuízo à moral ou à imagem"

\footnotetext{
${ }^{63}$ TRT3, RO n. 01602-2004-016-03-00-5, $2^{\text {a }}$ T., Rel. Juiz Jorge Berg de Mendonça, julg. 19.9.2006.

${ }^{64}$ RO n. 01873.2005.006.13.00-0, Trib. Pleno, Rel. Juiz Francisco de Assis Carvalho e Silva, julg. 21.9.2006.

${ }^{65}$ DELGADO, Maurício Godinho, Op. cit., p. 103.
} 


\subsection{DA COMPETÊNCIA DA JUSTIÇA DO TRABALHO:}

É recorrente nos julgados dos Tribunais Regionais do Trabalho e do Tribunal Superior do Trabalho a discussão sobre a (in)competência dos tribunais trabalhistas para julgar as causas que abarquem litígios, entre empregados e empregadores, em face de invento ou invenção por este desenvolvida.

As preliminares de incompetência ex ratione materiae são uníssonas ao alegarem que, nos ditames do artigo 14, IX, do texto constitucional, a Justiça do Trabalho tem a competência para dirimir, na forma da lei, outras controvérsias decorrentes da relação de trabalho; nestes termos, a indenização (matéria não trabalhista entre empregado e empregador) relativa a um invento desenvolvido pelo empregado não estaria abrangida na referida competência, pois não existiria expressa previsão legal neste sentido. Além disso, também é freqüente o argumento, em determinados casos, que o Poder Judiciário não poderia apreciar a indenização decorrente deste invento ou invenção, sem o prévio pronunciamento do INPI sobre a respectiva propriedade.

Ambas as argumentações, como é cediço na jurisprudência trabalhista, não merecem prosperar. $\mathrm{O}$ primeiro argumento interpreta de forma equivocada o artigo 114, da Constituição Federal, pois a natureza civilista da indenização (tema que será oportunamente abordado) não deve repelir, de pronto, a competência da justiça trabalhista; haja vista que o que se deve perquirir é se a respectiva invenção se deu (ou não) em razão daquela relação de emprego. Caso não seja possível desvincular a invenção ou o invento (este último no caso dos modelos de utilidade) desta relação empregatícia, justificada estará a competência da Justiça Especializada.

Esta defesa pela competência da Justiça do Trabalho desenvolve seu argumento na direção de que o aspecto crucial para determinação desta competência "é a presença de uma lide tipicamente entre empregado e 
empregador, em derivação do contrato de trabalho, colocando tais partes como credores e devedores recíprocos $"$ "66.

E é exatamente neste sentido que o TST consolida o seu entendimento, que remonta desde a vigência da Lei 5.772/71 e do artigo 454 da CLT, até a atual regulamentação pela Lei 9.279/96.

Nos ditames da lei anterior e do já revogado 454, da CLT, é possível extrair o seguinte entendimento:

"Não é porque o Código da Propriedade Industrial trata da invenção, que a matéria seria exclusiva da jurisdição civil, ainda mais quando há capítulo específico nessa lei cuidando "Do invento ocorrido na vigência do contrato de trabalho", disso também falando o vetusto art. 454 da CLT. A competência firma-se em decorrência do contrato de trabalho, sem o qual essa criação não teria ocorrido. (...) $\mathrm{O}$ Tribunal $a$ quo afastou a competência, baseando-se nas informações do Reclamante, segundo o qual os inventos e aperfeiçoamentos não decorriam de obrigações contratuais nem seriam inerentes à sua função. Ora, com o devido respeito, só isso não basta, a meu ver, para afastar a competência da Justiça do Trabalho; é incontroverso que os inventos ou aperfeiçoamentos ocorreram por causa do trabalho e no ambiente da empresa. Noutras palavras, a causa final foi a relação de trabalho!"67. (grifos nossos)

"A competência da Justiça do Trabalho para apreciar controvérsia em torno de invenção ou aperfeiçoamento, que não deixa de ser um trabalho inventivo, por parte do empregado, é determinada pela Lei 5.772/71 e artigo 454 da Consolidação das Leis do Trabalho, este abrangido pela referida lei e não revogado. A competência firma-se em decorrência do contrato de trabalho, sem o qual tal criação não teria ocorrido"68. (grifos nossos)

Em que pese a revogação do artigo 474, da CLT, e da Lei 5.772/71, a Justiça do Trabalho corrobora o entendimento, já consagrado pelo TST, da competência da justiça trabalhista aos casos de invento ou invenção do empregado, mas agora com fulcro na Lei 9.279/96. Neste sentido, confira-se os acórdãos do Tribunal Regional do Trabalho da $3^{\text {a }}$ Região:

"Entendo ser esta Justiça competente para apreciar o pedido de indenização ou de remuneração pela exploração, pelo empregador, de invento de autoria do empregado, desde que resultante da execução do contrato de trabalho ou de fato a este vinculado. Trata-se, sem dúvida, de controvérsia decorrente da relação de emprego, cuja

\footnotetext{
${ }^{66}$ DELGADO, Maurício Godinho, Direitos da Personalidade (Intelectuais e Morais) e Contrato de Emprego, in Revista do Tribunal Regional do Trabalho da $3^{a}$ Região, Belo Horizonte, n. 60, 1999, p.103. Nos ditames dessa linha interpretativa, apenas as relações jurídicas, ainda que oriundas do ambiente laboral, que não possuam como sujeitos característicos as figuras do empregado e do empregador é que não comportarão a competência da Justiça do Trabalho; a exemplo das lides previdenciárias, nas quais um dos sujeitos é o Estado.

67 TST, RR n. 593.729/99, $2^{\mathrm{a}}$ T., Rel. Juiz Convocado José Pedro Camargo, DJU de 16.2.01.

${ }^{68}$ TST, AIRR n. 433/1986-001-17.00, $4^{\mathrm{a}}$ T., Rel. Min. Milton de Moura França, julg. 14.4.04.
} 
competência para conciliar, instruir e julgar é atribuída à Justiça do Trabalho pelo art. 114 da Constituição Federal. Não importa a natureza civil do objeto do pedido. O que interessa é o fato de incluir-se ele no conteúdo do Direito do Trabalho. No caso dos autos, a alegada invenção só teria ocorrido em razão da existência do contrato de trabalho (...)"69.

“(...) a participação do empregado no processo de invenção é fato ínsito à interação entre este e a empresa, evidenciada pela existência de uma relação trabalhista. Tanto assim que a lei deixa claro que essa participação é oriunda de uma fusão entre a criatividade do inventor, na qualidade de empregado e dos recursos colocados à disposição, pelo empregador. Ou seja, o fato de referida participação ser disciplinada por lei específica, no caso, a denominada "Lei de Patentes", não lhe retira a condição de parcela devida em decorrência da atividade criativa desenvolvida pelo inventor na condição de empregado, o que, por si só, denota o caráter trabalhista com que a mesma se reveste" ${ }^{\prime 70}$.

Já em relação ao argumento de que a Justiça do Trabalho seria incompetente face à natureza civilista da indenização, esclarecedora é a decisão do STF, nas palavras do Ministro Sepúlveda Pertence, ao dispor sobre a promessa de compra e venda:

"Como resulta do artigo 114, no que interessa, a Constituição cometeu à Justiça do Trabalho conciliar e julgar os dissídios individuais e coletivos entre trabalhadores e empregadores, dissídios, porém, que há de ser os decorrentes da relação de trabalho (...). O fundamental é que a relação jurídica alegada como suporte do pedido esteja vinculada, como efeito à sua causa, à relação empregatícia, como parece inquestionável que se passa aqui, não obstante o seu conteúdo específico seja o de promessa de venda, instituto de direito civil". ${ }^{71}$

Por fim, também não merece prosperar o argumento de que a Justiça do Trabalho será incompetente para decidir sobre a indenização pleiteada, caso o INPI ainda não tenha decidido acerca da propriedade do invento ou da invenção, pois o que se deve ter em voga é o proveito econômico auferido pelo empregador em face da atividade inventiva do empregado, independente de haver ou não o depósito de patente. Na Justiça do Trabalho "não se discute a propriedade da patente; há que se perquirir se os inventos e aperfeiçoamentos foram resultado do

\footnotetext{
${ }^{69}$ RO n. 01504-1999-021-03-00-5, 4 ${ }^{\text {a }}$ T., rel. Juiz Convocado Fernando Luiz Gonçalves Rios Neto, julg. 17.12.02.

${ }^{70}$ RO n. 00459-2008-049-03-00-9, T. Recursal de Juiz de Fora, Rel. Juiz Jorge Berg de Mendonça, julg. 24.9.2008.

${ }^{71}$ Conflito de Jurisdição n. 6.959-6, Pleno, Rel. Min. Sepúlveda Pertence, julg. 23.5.90. Acórdão exposto por Valdir Florindo, em seu artigo A Justiça do Trabalho e o Dano Moral Decorrente da Relação de Emprego, in Revista de Direito do Trabalho, n. 27, Rio de Janeiro, 1995, pp. 321-323.
} 
contrato de trabalho, inclusive com o uso das máquinas e das instalações da empresa" ${ }^{, 72}$. Ainda neste sentido, dispõe o TRT da $3^{\text {a }}$ Região:

"Apenas para esclarecer eventuais dúvidas, ressalta-se que esta Especializada não tem o condão de declarar a propriedade do invento a nenhum dos demandantes, nem está adstrita a esperar a manifestação do INPI a respeito dela. Todavia, tem a competência para apreciar o pedido de indenização ou remuneração da execução do contrato de trabalho ou de fato a este vinculado, uma vez que o conflito é decorrente da relação de emprego",73.

Esta orientação é de grande relevância, pois se a Justiça do Trabalho deixar de reconhecer os direitos do empregado pelo fato de não ter havido prévia manifestação do INPI, haverá incentivo para que os empregadores mantenham a invenção em sigilo, não depositando o pedido de patente perante a autarquia, com o único escopo de não pagar o empregado pela fruição econômica do invento.

\footnotetext{
${ }^{72}$ TST, RR n. 593.729/99, $2^{\mathrm{a}}$ T., Rel. Juiz Convocado José Pedro Camargo, DJU de 16.2.01.

${ }^{73}$ RO n. 00957-2007-094-03-00-5, $3^{\text {a }}$ T., Rel. Juiz Convocado Milton Vasques Thibau de Almeida, julg. 25.7.08. Em sentido diverso e isolado, a $4^{\mathrm{a}}$ T., do TRT da $3^{\mathrm{a}}$ Região, dispõe que: "Os direitos do empregado pelas invenções e modelos de utilidade sempre foram regulados pelos denominados Códigos de Propriedade Industrial, anteriormente a Lei n 5.772/71, e atualmente a Lei n 9.279/96, e da leitura de suas disposições ressai que o empregado só poderá pretender os direitos daí decorrentes se, efetivamente, os seus inventos ou modelos receberam o registro previsto em lei". (TRT3, RO 15491/00, 4 ${ }^{\mathrm{a}}$ T., Relator Juiz Convocado João Bosco Pinto Lara, julg. 30.5.01)
} 


\section{AS ESPÉCIES DE INVENÇÃO OU INVENTO DO EMPREGADO:}

\subsection{DAS INVENÇÕES OU INVENTOS DE SERVIÇO:}

O contrato de trabalho não é estranho ao aprimoramento tecnológico. Nas lições de Carlos Henrique da Silva Zangrando:

"Na verdade, existem empregados cujo objeto do contrato de trabalho é justamente a invenção de algum aparelho, a descoberta de alguma nova tecnologia ou aprimoramento das existentes. É o caso dos técnicos altamente especializados, contratados para levar a cabo as pesquisas e testes necessários para a produção de novo medicamento, programas de computador, equipamentos ou máquinas" ${ }^{\text {74 }}$.

Nestes termos, de acordo com o artigo 88, da Lei 9.279/1996, a invenção e o modelo de utilidade irão pertencer exclusivamente ao empregador quando "decorrerem de contrato de trabalho cuja execução ocorra no Brasil e que tenha por objeto a pesquisa ou a atividade inventiva, ou resulte esta da natureza dos serviços para os quais foi o empregado contratado".

Neste sentido, o Tribunal Regional do Trabalho da $15^{\text {a }}$ Região assim decidiu:

"O aperfeiçoamento industrial decorreu das funções para a qual foi contratado o Reclamante, a qual tinha por "finalidade desenvolver o equipamento denominado "máquina centrífuga"”, sendo da natureza do próprio contrato que tinha por objeto "desenvolver referido equipamento e cuidar de sua comercialização" $"$.

Neste caso, como ensina Orlando Gomes e Elson Gottschalk, "a propriedade da patente é do empregador, que pode explorar livremente a invenção, respeitada a paternidade do invento pelo interesse moral dele resultante para o inventor",76.

Assim, para a conceituação das invenções ou inventos de serviços faz-se necessária a existência de um contrato de trabalho em vigor, a

\footnotetext{
74 ZANGRANDO, Carlos Henrique da Silva, Resumo do Direito do Trabalho, Rio de Janeiro: Trabalhistas, 2003, p. 308.

${ }_{75}^{75}$ RO n. 17074/96-6, 1 ${ }^{\text {a }}$ T., Rel. Juiz Luiz Antonio Lazarim, julg. 3.7.1996.

${ }^{76}$ Curso de Direito do Trabalho, Rio de Janeiro: Forense, 2007, p. 222.
} 
existência da invenção ou invento e a previsão da incumbência do empregado de executar atividades inventivas.

Sobre o último requisito, a lei faz algumas distinções que devem ser consideradas. Primeiramente, ela fala em pesquisa ou atividade inventiva, logo, a lei cogita a possibilidade de ambas as atividades, distintas a seu turno, levarem à ocorrência de invenção ou invento de serviço.

A distinção entre estas atividades reside no fato de que, quem é contratado para a atividade de pesquisa pode realizar tanto descoberta, quanto, invenção, cabendo neste último caso, o depósito, perante o INPI, do pedido de patente; enquanto que quem é contratado para realizar atividade inventiva buscará sempre a realização da invenção ou invento.

A lei ainda prevê a possibilidade de esta atividade inventiva resultar da natureza dos serviços para os quais o empregado fora contratado, sendo, por conseguinte, implicitamente prevista. Nuno Carvalho cita como exemplo esclarecedor, a hipótese de um técnico contratado para resolver um problema de operação de uma máquina:

\begin{abstract}
"Essa máquina produz $x$, mas a empresa precisa que ela produza $y$. A empresa contrata então alguém a quem atribui às funções de fazer com que a máquina atinja aquele resultado. Claro, o contrato não prevê diretamente a atividade inventiva. Mas esta pode ocorrer, de modo indireto. Basta que, ao pesquisar as soluções já existentes para o mesmo problema, o técnico contratado não encontre alguma que o satisfaça, preferindo então exercer a sua criatividade para conseguir o resultado pretendido pela empresa contratante. Vale dizer, (...) o contrato teria por objeto a busca de uma solução para um problema técnico. A invenção não está aí expressamente prevista, mas ela seria um resultado natural da atividade contratada" ${ }^{\text {7 }}$.
\end{abstract}

Assim, a análise será casuística, por intermédio da observância do contrato de trabalho do empregado, bem como das circunstâncias concretas que decorreram na invenção ou no invento. Mas, vale observar que o invento ou invenção só serão de serviço quando existir conexão entre a sua aplicação prática e a atividade desempenhada pelo empregador, caso o empregado não tenha sido expressamente contratado para tanto ${ }^{78}$. Assim, no

\footnotetext{
${ }^{77}$ CARVAlHO, Nuno T. P., Os Inventos de Empregados na Nova Lei de Patentes - II, in Revista da ABPI, n. 23, Rio de Janeiro: Garilli Gráfica, 1996, p.4.

${ }^{78}$ Nada impede que o empregador deseje ampliar as atividades desenvolvidas pela empresa e resolva contratar empregados para desenvolverem tecnologias neste novo setor em que deseje
} 
exemplo acima, deverá a invenção decorrente do conserto da máquina ter aplicação na linha de produção do empregador, contribuindo, mesmo que de maneira indireta, no processo produtivo da empresa; sob pena de não ser de propriedade exclusiva do empregador.

Dessa forma, a análise do contrato social, ou do estatuto da empresa, servirá para detectar quais as atividades principais desenvolvidas, que irão ensejar a propriedade da invenção ou do invento pelo empregador, e quais são acessórias, e, neste último caso, não se tratará de propriedade exclusiva do empregador. Assim, só será de propriedade exclusiva do empregador, o invento ou invenção que puder ser aplicado na própria linha de produção da empresa.

As hipóteses de justa causa para rescisão do contrato de trabalho pelo empregador, previstas nas alíneas " $c$ " e " $g$ ", do artigo 482, da CLT, também desempenham importante papel na identificação do tipo de invenção ou invento, no caso concreto. Há que se perquirir se caso o empregado explore ou revele a terceiros o seu invento ou invenção, ele implicará em falta grave de "ato de concorrência" ou de "violação de segredo de empresa" respectivamente ${ }^{79}$. Caso ele incida em uma destas hipóteses previstas na CLT, esta invenção será de serviço.

Mas, obviamente estes parâmetros não são rígidos, pois, tal como visto, a análise deverá ser casuística.

\subsection{A REMUNERAÇÃO DO EMPREGADO INVENTOR NAS INVENÇÕES OU INVENTOS DE SERVIÇO:}

O $\S 1^{\circ}$, do artigo 88, da Lei 9.279/1996, dispõe que, salvo expressa disposição contratual em contrário, a retribuição pelo trabalho, no caso das invenções ou inventos de serviço, limita-se ao salário ajustado.

\footnotetext{
operar. Em ditos casos, ainda que, a priori, a invenção não tenha conexão com a atividade desenvolvida pela empresa, ela será de serviço, haja vista que a contratação visava, justamente, à ampliação do rol das atividades empresariais. Neste caso, não caberá, portanto, pagamento adicional ao salário ajustado.

${ }^{79}$ Do artigo 482, da CLT, infere-se que o empregado deve não apenas comunicar ao empregador a realização de invenção de serviço, como também, ele deverá guardar sigilo sobre esta.
} 
Aplicando este dispositivo, ao caso concreto, o Tribunal Regional do Trabalho da $10^{\mathrm{a}}$ Região assim dispôs:

"A invenção exige a criação de objeto que observe os requisitos da novidade, para aplicação industrial, assim imprescindível produto novo ou resultado novo. Ademais, quando contratado obreiro expressamente para a criação de modelo de utilidade ou invenção, o salário já remunera a criação e o produto novo ao patrimônio do empregador (...)" ${ }^{\prime 80}$.

Em que pese o caso concreto, é comum que as empresas, com o escopo de incentivarem os seus empregados a alcançarem resultados eficazes prevejam nos seus regulamentos internos a possibilidade de pagamento de prêmios-produção.

Neste sentido, Sérgio Pinto Martins afirma que:

"Inexistirá obrigação do empregador em conceder ao empregado resultados da exploração da patente, sendo mera faculdade, que pode ou não ser exercitada pelo empregador. A participação a qualquer título não se incorpora a salário do empregado. Não tem, portanto, natureza salarial a retribuição efetuada pelo empregador, nem terá efeitos reflexos em outras verbas trabalhistas" ${ }^{\prime 1}$.

Mas, para não suscitar dúvidas quanto à natureza deste pagamento, a Lei 9.279/1996 o toma, de pronto, como uma liberalidade por parte do empregador ao explicitar, em seu artigo 89, que:

"O empregador, titular da patente, poderá conceder ao empregado, autor de invento ou aperfeiçoamento, participação nos ganhos econômicos resultantes da exploração da patente, mediante negociação com o interessado ou conforme disposto em norma da empresa. Parágrafo único. A participação referida neste artigo não se incorpora, a qualquer título, ao salário do empregado." (grifos nossos)

Nesta seara, as divergências doutrinárias afloram, pois há posicionamento no sentido de que ao empregado inventor somente lhe é devido o salário e qualquer pagamento a mais seria mera liberalidade do empregador, nos ditames do que a lei preceitua; mas, também existem autores se opõem a esta idéia.

$\mathrm{Na}$ linha deste último posicionamento doutrinário, tal qual visto anteriormente, há quem pondere que se houver flagrante desproporcionalidade entre a remuneração do empregado e os resultados

\footnotetext{
${ }^{80}$ RO n. 00056-2007-007-10-00-9, 22 T., Rel. Juiz Alexandre Nery de Oliveira, julg. 30.4.2008.

${ }^{81}$ Comentários à CLT, São Paulo: Atlas, 2003, p. 381.
} 
econômicos auferidos pelo empregador, ao primeiro será devida alguma participação nos lucros da invenção ou invento, haja vista que, se assim não ocorrer, estar-se-á autorizando o enriquecimento sem causa.

Os opositores a esta teoria rebatem este argumento alegando que:

“(...) se o que importa é a proporção das contribuições econômicas dos sois pólos do contrato de trabalho, então haveria que se cogitar também pela compensação ao patrão em caso de insucessos repetidos pelo inventor - afinal, (...) a atividade inventiva é essencialmente aleatória. Portanto, se ao patrão fosse imposta uma obrigação de suplementar a remuneração do inventor excepcionalmente bem sucedido, em tese o inventor mal sucedido deveria compensar o patrão pela ausência do sucesso (por exemplo, devolvendo o salário)" ${ }^{\text {"2 }}$.

No entanto, frente ao radicalismo deste posicionamento, Nuno Carvalho pondera que "os opositores da idéia esquecem que para o inventor mal sucedido o mercado já tem uma resposta: ele acabará perdendo o emprego" $" 83$.

\subsubsection{O ARTIGO 88, § 20, DA LEI 9.279/1996 E A TENTATIVA DE COIBIR O COMETIMENTO DE FRAUDE PELO EMPREGADO:}

Tendo em vista que as invenções de serviço são exclusivamente propriedade do empregador, o empregado, com o escopo de auferir lucros, poderia ocultar o invento ou invenção do empregador, para depois rescindir o contrato e iniciar sozinho a exploração deste; ou ainda, poderia, em face deste know-how, negociar com o concorrente, do antigo empregador, condições de trabalho e salário mais vantajosas.

Para inibir tais condutas dotadas de má-fé, o $\S 2^{\circ}$, do artigo 88 , da Lei 9.279/1996, preceitua que:

"Salvo prova em contrário, consideram-se desenvolvidos na vigência do contrato a invenção ou o modelo de utilidade, cuja patente seja requerida pelo empregado até 1 (um) ano após a extinção do vínculo empregatício".

Assim, em vista do "salvo prova em contrário" é possível depreender que esta presunção não é absoluta, podendo, portanto, ser elidida por prova,

\footnotetext{
${ }^{82}$ CARVALHO, Nuno T. P., Op. cit., p.9.

${ }^{83}$ Ibid. p. 9.
} 
em contrário, do empregado. A este caberá provar que a idéia inventiva, ensejadora da invenção ou invento, surgiu posteriormente à extinta relação de trabalho. Assim, ainda que os trabalhos preparatórios tenham se iniciado na antiga empregadora, se o empregado conseguir provar que a idéia inventiva só surgiu depois da rescisão do vínculo empregatício, a ele caberá fruir a obra.

Com relação ao ônus da prova, cabem algumas considerações em relação a este prazo de um ano. Caso o depósito do pedido de patente tenha sido efetuado pelo empregado depois da extinção do contrato de trabalho dentro de um ano, a este caberá o ônus de provar que a idéia inventiva surgiu posteriormente à extinção deste vínculo. No entanto, se o depósito do pedido de patente pelo empregado se der depois deste prazo de um ano, a presunção juris tantum opera em prol do ex-empregado, cabendo, portanto, o ônus da prova ao ex-empregador.

\subsection{DAS INVENÇÕES OU INVENTOS LIVRES:}

O artigo 90, da Lei 9.279/1996, dispõe que:

"Pertencerá exclusivamente ao empregado a invenção ou o modelo de utilidade por ele desenvolvido, desde que desvinculado do contrato de trabalho e não decorrente da utilização de recursos, meios, dados, materiais, instalações ou equipamentos do empregador".

Este artigo da lei, na mesma linha do Código de 1971, atribui a titularidade da invenção ou invento apenas ao empregado, quando este os desenvolver fora do contrato de trabalho e sem a utilização de recursos do empregador. Assim, a cláusula do contrato de trabalho que dispuser em sentido diverso será nula e o empregador será verdadeiro contrafator. Dessa forma, como a discussão dar-se-á fora das relações empregatícias e a discussão se funda em ato ilícito cometido pelo empregador, a competência, em ditos casos, será da Justiça Comum para apreciar a lide. 
No entanto, nada impede que exista cláusula que atribua ao empregador direito de preferência na exploração da invenção, mas para tanto, não pode haver coação ou pré-fixação das condições de transferência.

Caso não haja qualquer previsão contratual, nada impede que o empregador, que possua interesse em explorar economicamente a invenção, negocie com o seu empregado. Mas esta negociação dar-se-á como se estes estranhos fossem, sem qualquer relação com o vínculo empregatício existente entre eles. "Aqui, autoria e titularidade patentária concentram-se numa só pessoa, o empregado" $" 84$.

Corroborando o acima exposto, o Tribunal Regional do Trabalho da $4^{\mathrm{a}}$ Região assim expôs:

“(...) os produtos comprovadamente inventados pelo reclamante, ora embargante, ou seja, aqueles registrados em seu nome no Instituto Nacional da Propriedade Industrial, (...) e que na sua confecção não tiveram qualquer participação do empregador, pertencem exclusivamente a si. (...) os litígios decorrentes de invenção livre, fazer cessão de seu direito a qualquer fabricante, seu empregador ou não, tal contrato é semelhante ao de Locação de Coisas ou Contrato de Licença (...), sendo litígios decorrentes deste tipo de Contratos, pela sua natureza, são de competência da Justiça Comum" ${ }^{\text {"85 }}$.

O empregado, exclusivo proprietário da patente que porventura será expedida, não possui o dever de comunicar ao empregador a realização de suas invenções livres e poderá licenciá-la a terceiros sem quaisquer problemas. Em contrapartida, se a invenção interessar à atividade do empregador, nos ditames da lealdade, o empregado deve notificá-lo da sua invenção, sob pena exercer atividade concorrencial ao seu empregador.

\subsection{DAS INVENÇÕES OU INVENTOS MISTOS OU DEPENDENTES OU OCASIONAIS:}

Os inventos mistos vêm preceituados no artigo 91, da Lei 9.279/1996, que assim dispõe:

"A propriedade de invenção ou de modelo de utilidade será comum, em partes iguais, quando resultar da contribuição pessoal do empregado e de recursos,

\footnotetext{
${ }^{84}$ TEIXEIRA FILHO, João de Lima, Op. cit., p. 261.

${ }^{85}$ RO n. 01606.008/93-5, 2a T., Rel. Juiz Álvaro Davi Boessio, julg. 12.1.1999.
} 
dados, meios, materiais, instalações ou equipamentos do empregador, ressalvada expressa disposição contratual em contrário".

Nestes termos, três são os requisitos que devem ser observados para que a invenção seja conceituada como mista: i) deve decorrer de contribuição pessoal do empregado (pode ocorrer a contribuição pessoal de outros empregados também); ii) o empregado não deve ter sido contratado para inventar; e iii) para exteriorizar a sua idéia inventiva, o empregado se utilizou de recursos, dados, materiais, instalações ou equipamentos do empregador.

Como exemplo bem ilustrativo destes requisitos, vale citar acórdão do TST:

"Incontroverso nos autos que o Autor utilizou-se da estrutura, dos insumos e equipamentos da Reclamada, atuando Como colaborador na formulação de um molho, havendo conjugação de esforços com o engenheiro na fixação dos percentuais, tanto na base científica (engenharia e química) como em relação à pesquisa realizada, devida indenização pelo invento, vez que o desenvolvimento da atividade não estava vinculado ao contrato de trabalho" ${ }^{" 86}$.

O primeiro requisito da contribuição pessoal do empregado remonta à idéia de que este deve ter participado e contribuído diretamente para o resultado do processo inventivo; assim, o mero trabalho de apoio e de coleta de dados não legitima o empregado a participar nos ganhos da exploração do invento.

Dispondo sobre este requisito da contribuição pessoal do empregado, o Tribunal Regional do Trabalho, da $4^{\mathrm{a}}$ Região, concorda com a decisão $a$ quo que expõe que:

“(...) a simples contribuição com idéias e em conjunto com outros profissionais para a confecção de dispositivos que atendam as necessidades da demandada, não caracteriza invenção ou modelo de utilidade. (...) Como se vê das conclusões periciais, não se trata propriamente de um invento ou modelo de utilidade, mas sim de adaptações a dispositivos, que resultaram da natureza do trabalho prestado pelo reclamante e seus colegas à empresa. Tais adaptações não se revestem de caráter de ineditismo que caracteriza o invento, pois como referido pelo perito oficial (...) existem dispositivos similares no mercado" ${ }^{\text {" } 7}$.

\footnotetext{
${ }^{86}$ AIRR n. 712/2005-051-18-40, $6{ }^{\text {a }}$ T., Rel. Min. Aloysio Corrêa da Veiga, julg. 3.10.2007.

${ }^{87}$ RO n. 00255-2006-252-04-00-0, $3^{\mathrm{a}}$ T., Rel. Juiz Luiz Alberto de Vargas, julg. 16.4.2008.
} 
Assim, no caso acima, mesmo que os dispositivos desenvolvidos caracterizassem invenção ou invento, certo é que ao reclamante não lhe caberia quaisquer indenizações, haja vista que lhe faltou o requisito essencial da contribuição pessoal do empregado.

Em segundo lugar, o empregado não deve ter sido contratado para inventar, pois se assim o fosse, tratar-se-ia de invenção de serviço e não de invenção mista. Neste segundo requisito, ainda que pareça simples sob uma primeira análise, em realidade, ele deve ser visto com cuidado, pois, pode suscitar problemas na análise casuística.

Por exemplo, existem contratos de trabalho dotados de cláusulas um tanto genéricas quanto às atribuições do empregado, de modo que não é possível definir, de pronto, se este abrange, ou não, a atividade inventiva. Diante de tais casos, faz-se necessária a análise das incumbências inicialmente passadas ao empregado ${ }^{88}$. Caso este seja inicialmente responsável por atividade desvinculada do processo inventivo e posteriormente seja realocado para o exercício de atividade inventiva, sem a conseguinte compensação salarial para tanto, não se pode concluir que as invenções por ele desenvolvidas serão de serviço, pois, tal como visto, em tais casos, nada será devido ao empregado.

Como segundo exemplo casuístico, a empresa, buscando se desvencilhar da invenção mista, poderá dispor, no contrato de trabalho, cláusula padrão de cessão das invenções ou inventos, porventura desenvolvidos, ao empregador, independentemente do objetivo para o qual o empregado fora contratado.

\footnotetext{
${ }^{88}$ Como exemplo desta hipótese, segue acórdão do Tribunal Regional do Trabalho da $4^{\mathrm{a}}$ Região: "O Reclamante como gerente de produção, embora tivesse conhecimento do que a empresa industrializava não participava da elaboração de projetos, nem do aperfeiçoamento de qualquer peça, até mesmo por que este processo exige pessoas qualificadas e o Reclamante possui apenas o primeiro grau completo, não possui o conhecimento técnico específico para elaboração de desenhos industriais de produtos, ferramentas, modelagem de produto, etc (...). Como o aperfeiçoamento ocorreu com os recursos da empresa-ré, o caso vertente enquadra-se na terceira hipótese legal, prevista no art. 91 da Lei 9.279/96, sendo o invento de propriedade comum, em partes iguais". (...) Desse modo, é devido ao autor o pagamento de indenização que se fixa no índice de $15 \%$ sobre o valor de cada peça "Santo Antônio" vendida - que continua sendo comercializada, segundo consulta ao site www.bepo.com.br - desde o aperfeiçoamento realizado pelo autor até a data do início da execução, a ser apurado em liquidação de sentença (...)”. (RO n. 01612-2005-404-04-00-9, 1ª T., Rel. Juiz José Felipe Ledur, julg. 9.11.2006).
} 
Esta cláusula, por si só, não elide a figura da invenção mista, haja vista que, se assim o fosse abrir-se-ia espaço para o cometimento de fraudes por parte do empregador, que estabeleceria esta cláusula indiscriminadamente para nunca ter que repartir os lucros obtidos com o invento com o seu empregado. Como dito, há que se vislumbrar o objetivo inicial da contratação daquele empregado ${ }^{89}$, para só então ser possível concluir pela invenção mista ou pela invenção de serviço.

Em caso concreto sobre cláusula padrão dispondo sobre a cessão de direitos sobre invenção ou invento futuro, o TST assim decidiu:

"Considerada a função do reclamante, não se há falar (sic) que seu invento ocorreu como parte da previsão ou dinâmica contratual empregatícias, pois o projeto desenvolvido estava totalmente dissociado de seu pacto laboral, não se inserindo entre suas tarefas originalmente estabelecidas. Não obstante a idéia útil trazida pelo reclamante, com a criação de melhoria no atendimento do cliente, não guardasse relação com o contrato laboral, conforme se infere da cláusula $7^{\text {a }}$ do contrato de trabalho dele, restou pactuado no seu item $1^{\circ}$ que 'o empregado concorda em divulgar e ceder à empregadora ou a seu nomeado todos os seus direitos a invenções feitas ou concebidas por ele, seja isolada ou conjuntamente com outros empregados, durante a vigência deste contrato, considerando-se, inclusive, a eventual prorrogação do mesmo.' Ora, essa cláusula não pode ser acolhida, pois abusiva, contemplando uma situação totalmente alheia à contratação de um profissional cuja atividade não gera a expectativa de criação original de inventos ou utilidades que incrementem o empreendimento explorado pelo empregador. Aplica-se ao caso o art. $9^{\circ}$ da CLT, considerando-se nula de pleno direito a cláusula contratual estabelecida com o objetivo de impedir a aplicação dos preceitos contidos na CLT",90.

Deste acórdão é possível extrair o princípio da primazia da realidade, do Direito do Trabalho, de onde se conclui que:

“(...) resulta errôneo pretender julgar a natureza de uma relação de acordo com o que as partes tiverem pactuado, uma vez que, se as estipulações consignadas no contrato não correspondem à realidade, carecerão de qualquer valor" ${ }^{\prime 91}$.

\footnotetext{
${ }^{89}$ Antes de decidir pelo tipo de invenção ou invento que se aplica ao caso concreto, não basta, portanto, que o magistrado olhe apenas para a atividade atual do empregado, mas ele deve estar atento para a função inicialmente contratada, para que não haja prejuízo ao empregado inventor. Atentando para tal fato, o Tribunal Regional da $3^{\text {a }}$ Região assim dispôs: "Considerada a função do reclamante, não há de se falar que seu invento ocorreu como parte da previsão ou dinâmica contratual empregatícias, pois o projeto desenvolvido estava totalmente dissociado de seu pacto laboral, não se inserindo entre as tarefas originalmente estabelecidas". (grifos nossos) (RO n. 00305-2007-003-03-00-9, $1^{\text {a }}$ T., Rel. Juiz Maurício Godinho Delgado, julg. 27.8.2007)

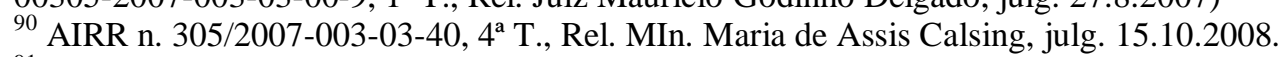

${ }^{91}$ RODRIGUEZ, Américo Plá, Princípios de Direito do Trabalho, São Paulo: LTr, 2000, p. 340.
} 
Assim, a interpretação do contrato deve ser feita de maneira sistemática, para que não se legitime a intenção de fraude do empregador, em face de seu empregado inventor. Quando se trata de invenção de serviço, ou seja, quando o empregado é contratado para inventar, o salário do empregado já é avençado com um quantum superior, pois certo é que este não poderá obter a fruição econômica da invenção (que pertence exclusivamente ao empregador). No entanto, se o empregado não é contratado para esta finalidade e porventura desenvolve invenção, este terá participação nos lucros, já que o salário inicialmente pactuado não previa tal possibilidade.

Dessa forma, se esta cláusula padrão de cessão de direitos sob a invenção for tomada como válida neste último caso, o inventor não terá direito a nenhuma participação nos lucros e será substancialmente prejudicado, pois o salário pactuado inicialmente não vislumbrou esta hipótese de ocorrência da atividade inventiva; razão, pela qual, esta cláusula deverá ser tida como nula, pois deve vigorar o princípio do contratorealidade.

Ainda nos ditames do acórdão acima citado, claro é posicionamento do TST, neste sentido, ao afirmar que:

"Como o projeto desenvolvido pelo obreiro extrapolou o objeto do contrato,
considera-se que o valor ajustado para o salário não remunerou a inovação trazida
para a empresa pelo reclamante denominada 'Projeto Carona'. Na verdade, ao
ingressar na reclamada, não se pode considerar que o reclamante tenha abdicado
do direito de reivindicar a autoria da sua criação, não incluída nas suas funções
contratuais" Esta mesma linha expositiva valerá para o caso de desvio de função do empregado. Caso o empregador destine um empregado para o desempenho de uma atividade inventiva, atividade esta para qual ele não fora inicialmente contratado, diante da falta de aumento salarial, para a compatibilização com a nova função, o empregado poderá pleitear os

\footnotetext{
${ }^{92}$ AIRR n. 305/2007-003-03-40, 4ª T., Rel. MIn. Maria de Assis Calsing, julg. 15.10.2008.
} 
direitos a ele reconhecidos pelos artigos 460 e 461, da CLT ${ }^{93}$. No caso do último artigo, que trata de equiparação salarial, só será aplicável caso o empregador possua outros empregados contratados para o desempenho de atividade inventiva.

Mas, caso o empregado assim não proceda e caso o empregador venha a alcançar a propriedade exclusiva da invenção ou invento, esta mudança unilateral do contrato pelo empregador não será válida, de forma que a invenção deve ser tida como mista, e não como de serviço.

\subsubsection{A EXPLORAÇÃO DAS INVENÇÕES OU DOS INVENTOS MISTOS:}

Tal qual preceituado no artigo 91 (supracitado), da Lei 9.279/1996, a propriedade, no caso das invenções mistas, será comum ao empregado e ao empregador, no entanto, caberá a este último o direito exclusivo de exploração, cabendo, em contrapartida, ao inventor uma participação nos lucros auferidos.

Dependendo da invenção, a contribuição do empregador para a invenção poderá ser maior, ou menor, no entanto, nem sempre é fácil mensurar o grau desta participação. Assim, o legislador adotou, a princípio, a postura de dividir, em partes economicamente equivalentes, as contribuições do empregado e do empregador. Assim, estabelece-se verdadeira co-propriedade (ou compropriedade) entre empregado e empregador.

Este condomínio legal entre empregador e empregado deve ser analisado com cuidado, haja vista que:

\footnotetext{
${ }^{93}$ Art. 460 - Na falta de estipulação do salário ou não havendo prova sobre a importância ajustada, o empregado terá direito a perceber salário igual ao daquela que, na mesma empresa, fizer serviço equivalente ou do que for habitualmente pago para serviço semelhante.

Art. 461 - Sendo idêntica a função, a todo trabalho de igual valor, prestado ao mesmo empregador, na mesma localidade, corresponderá igual salário, sem distinção de sexo, nacionalidade ou idade. § $1^{\circ}$ - Trabalho de igual valor, para os fins deste Capítulo, será o que for feito com igual produtividade e com a mesma perfeição técnica, entre pessoas cuja diferença de tempo de serviço não for superior a 2 (dois) anos.
} 
“(...) a situação de condomínio ou compropriedade da invenção não significa que cada co-proprietário seja dono de uma parte ou percentual do invento, que é indivisível, mas sim que cada um, sendo dono da totalidade do invento, tem direitos qualitativamente iguais sobre a invenção, direitos estes limitados, contudo, pela situação de condomínio imposta pela lei e regulada pelos arts. 1314 e seguintes do Código Civil atualmente em vigor" ${ }^{\text {"94. }}$.

Nestes termos, a lei faculta o licenciamento exclusivo ao empregador para que realize a exploração econômica do invento ou invenção. Este licenciamento exclusivo tem por escopo assegurar que o empregado não realize concorrência desleal ao seu empregador, ao licenciar àquele invento a terceiros ${ }^{95}$.

No entanto, há que se buscar uma parcimônia interpretativa do dispositivo, pois como se trata de co-propriedade, não se pode elidir, em definitivo, a possibilidade do empregado inventor também explorar a sua invenção. Mas levando em conta que a própria legislação trabalhista veda a concorrência com o patrão, este empregado só poderia explorar também a invenção ao término do vínculo empregatício ${ }^{96}$. Nesta exploração, é importante salientar, que o empregado deverá respeitar os segredos de empresa do ex-empregador, como o seu know-how, sob pena desta exploração ser ilegítima.

Nas invenções mistas, assim como nas invenções de serviço busca-se elidir a tentativa de fraude pelo empregado, que guarda para si a invenção e, ao término de vínculo empregatício, tenta ser o único proprietário da invenção. No entanto, se o empregado não foi contratado com o escopo de exercer a atividade inventiva, tal qual nas invenções de serviço, ainda que ele tenha tido a idéia inventiva quando da vigência do contrato de trabalho, se ele a concretizou apenas quando da extinção do vínculo empregatício, a invenção será livre, ou seja, de propriedade exclusiva do empregado.

\footnotetext{
94 Instituto Dannemann Siemsen de Estudo de Propriedade Industrial, Comentários à lei da Propriedade Industrial, Rio de Janeiro: Renovar, 2005, p.167.

${ }^{95} \mathrm{Se}$, por um lado, este direito de licenciamento não assiste ao empregado inventor, por outro lado, poderá o empregador licenciar a invenção ou invento a terceiros, até mesmo sem a anuência do empregado; mas a este último também caberá a fruição, pela metade, oriunda deste licenciamento.

${ }^{96}$ Desde que não haja celebração de pacto de não-concorrência com o empregador ao término do vínculo empregatício. Neste caso, este pacto deverá ajustar um pagamento adequado ao exempregado, já que ele não poderá explorar a invenção (ao menos por determinado lapso temporal).
} 
Ainda que o empregado sozinho tenha tido a idéia inventiva e a tenha concretizado pela utilização dos recursos do empregador, tal fato faz com que este tenha direito à co-propriedade. Este desdobramento encontra a sua fundamentação na figura da especificação do Direito Civil (já citada anteriormente), mas aqui, nas invenções mistas, o resultado obtido pelo inventor (especificador) não é concebido como mais valioso do que os recursos de outrem (empregador) por ele utilizados. Nos casos concretos, os recursos utilizados podem ser mais, ou bem menos, valiosos do que a invenção obtida. Assim, pelo sim e pelo não, vigorará a co-propriedade entre empregador e empregado ${ }^{97}$.

No entanto, como o empregado deve conceder exclusivamente os direitos de exploração da invenção ao empregador, com base nesta licença exclusiva, a ele será devida "justa remuneração", como estipula o $\S 2^{\circ}$, do artigo 91, da Lei 9.279/1996. Ou seja, dever-se-á tomar por base o valor intrínseco do invento ou invenção para fixar o quantum devido, decorrente do gozo de um bem. Nas lições de João de Lima Teixeira Filho:

"Significa que as partes devem avir compensação pecuniária equânime para o
empregado, sob pena de reversão à co-titularidade. Justa remuneração nada tem a
ver com natureza salarial. Afinal, esta cessão de direitos não resulta de
contraprestação se serviço contratado. A nosso ver, o propósito da lei é evitar que
o empregador, ao negociar a exclusividade, pague valor irrisório ao empregado
comparado ao faturamento líquido indicado nas avaliações de mercado de
domínio do empregador (...."98. Maurício Godinho Delgado complementa este entendimento ao analisar o vocábulo remuneração, utilizado tanto pelo antigo Código de 1971, quanto pela Lei 9.279/1996 em vigor:

“(...) embora ambos os textos legais valham-se do vocábulo remuneração, na verdade estão ambos se referindo a uma retribuição por título jurídico não trabalhista, isto é, um contrato paralelo ao contrato empregatício e a este acoplado. Isso fica claro ao se saber que o pagamento pelo invento seria feito mesmo que o inventor não fosse empregado, mas mero prestador autônomo de

\footnotetext{
${ }^{97}$ O direito de propriedade do empregador decorre de sua participação no processo inventivo, por intermédio de seus recursos, ainda que não tenha conhecimento disso. Assim, o estabelecimento da compropriedade não é uma indenização ao patrão pela utilização indevida de seus dados, meios, materiais, instalações, mas sim atribuição da co-titularidade pela sua participação no ato inventivo. ${ }^{98}$ Op. cit., p. 262.
} 
serviços. Desse modo, o pagamento tem como causa o invento e não a prestação de serviços ou o conteúdo contratual trabalhista". ${ }^{99}$

Nesta seara, não existe quaisquer vínculos entre a renda da propriedade e o salário pago ao empregado, pois o primeiro é recompensa secundária e indireta, que depende, para sua fixação, do valor econômico obtido pela disponibilização da invenção no mercado. A este valor alcançado, caberá a divisão, em parte iguais, entre empregado e empregador.

Esta divisão, em partes iguais, não é unânime na doutrina. $\mathrm{O}$ próprio TST apresenta as divergências doutrinárias e se posiciona:

"Catharino assim pensa ao afirmar que em hipótese que tais (sic), "o empregado
tem direito à metade dos resultados auferidos com a sua exploração". (...) Não
seria justa essa solução para o empregador, poderá Gama Cerqueira, pois "a
exploração do invento exigiria capitais e acarretaria trabalho, despesas e outros
onus, que só ele teria de suportar, podendo, ainda, dar prejuízos de que não
participaria o empregado". Cremos, pois, que o Projeto de Lei n. 824/91, ao
dispor que é assegurada ao empregado "justa remuneração", tem o mérito de
esclarecer não ser necessariamente devido ao empregado metade do lucro
auferido com a exploração do invento. Se não acertado pelas partes, de comum
acordo, o que será devido ao empregado pela exploração do invento, e sobrevindo
o litígio, o juiz determinará, segundo as circunstâncias do caso em concreto, qual
será a "justa remuneração" devida ao empregado. Poderá fazê-lo baseando-se em
resultado de perícia ou mesmo arbitramento, dentro dos princípios da eqüidade, e
tendo em vista o interesse social e econômico do País (....)"100. (grifos nossos) No caso de não haver qualquer retorno econômico, o empregado não fará jus a qualquer remuneração, haja vista a inexistência de quaisquer lucros para o empregador (continuando, ambos, como comproprietários da invenção ou invento).

É importante relembrar que, como visto no início deste trabalho, é a carta-patente que gera a propriedade, com a conseguinte oponibilidade erga omnes. No entanto, mesmo diante do não-depósito do pedido de patente, no caso de exploração econômica da invenção pelo empregador, caberá ao empregado a devida remuneração. A exploração econômica não consiste unicamente em fruir a invenção ou invento por intermédio de sua disponibilização do mercado, mas, se ela contribui, por exemplo, com uma

\footnotetext{
${ }^{99}$ Op. cit., p. 101.

100 AIRR n. 1504/1999-021-03-00, $5^{\text {a }}$ T., Rel. Juiz Convocado José Pedro de Camargo, julg. 31.8.2005.
} 
maior produtividade dentro da própria empresa, também há que se falar em exploração econômica, pois a invenção contribuirá para um aumento da lucratividade do empregador.

É o que dispõe o acórdão que se segue:

“(...) o dispositivo foi utilizado durante aproximadamente um ano enquanto durou o contrato de trabalho do reclamante (...), sendo que essa utilização, inequivocamente, representou eliminação de despesas para a reclamada, como a da disponibilidade de mão-de-obra, de despesas de transporte, etc. Desse modo, entendo razoável que a indenização em questão seja apurada por arbitramento, mediante perícia contábil a ser realizada na empresa, sendo fixada com base no percentual de $50 \%$ do lucro líquido auferido por ela em razão do invento, levando-se em conta a economia obtida pela desnecessidade de disposição de mão-de-obra, deslocamento de empregados, despesas de transporte e outros fatores, objetivos e materialmente apuráveis que a perícia apontar,"101.

Nos casos das invenções mistas também existe a possibilidade de inclusão de cláusula de cessão ao empregador, no âmbito do contrato de trabalho, mas esta se presume onerosa ${ }^{102}$, pois, tal como visto, muitas das vezes representam verdadeiras cláusulas-padrão. Nada impede que o empregado abra mão de sua remuneração, haja vista que se trata de direito patrimonial disponível. Mas é inconcebível se vislumbrar tal hipótese de gratuidade da cessão, em verdadeiro contrato de adesão, quando da configuração do vínculo empregatício.

Em tais casos, o empregador deverá pagar, pelo preço da cessão, exatamente a metade do que pagaria se estivesse negociando com terceiros, pois o que ocorre é a transferência da propriedade Assim, por se tratar da cessão de um bem, esta remuneração não tem natureza trabalhista, mas sim tem natureza de ordem civil.

Em relação à repartição dos lucros auferidos pelo empregador, João da Gama Cerqueira realiza críticas ao dispositivo aplicável na legislação anterior, mas a sua crítica continua sendo atual mesmo diante do novo diploma legal. Assim, ele argumenta que:

101 TRT3, RO n. 01602-2004-016-03-00-5, $2^{\text {a }}$ T., Rel. Juiz Jorge Berg de Mendonça, julg. 19.9.2006.

${ }^{102} \mathrm{O}$ valor pago ao empregado pela cessão pode ser revisto posteriormente, no caso de a invenção porventura revelar-se mais lucrativa do que se vislumbrava a princípio. 
“(...) o Código não estabeleceu simples comunhão, mas sociedade entre empregador e empregado. Comunhão na propriedade do invento e sociedade na sua exploração. Sociedade em que predominaria fatalmente a desigualdade fundamental da situação das partes e que daria, na maioria dos casos, desfavoráveis resultados para a parte mais fraca e desprotegida. O empregado, em regra, ficara desamparado na defesa dos seus direitos e interesses, à mercê do empregador, sem meios eficazes para compeli-lo ao cumprimento de suas obrigações e para fiscalizar a exploração do invento" 103 .

Superada a discussão acima, é importante salientar que a inércia injustificada ${ }^{104}$ do patrão em explorar a invenção ou invento faz com que a propriedade passe exclusivamente para as mãos do empregado, no termos do $§ 3^{\circ}$, do artigo 91, da Lei 9.279/1996, que assim dispõe:

“A exploração do objeto da patente, na falta de acordo, deverá ser iniciada pelo empregador dentro do prazo de 1 (um) ano, contado da data de sua concessão, sob pena de passar à exclusiva propriedade do empregado a titularidade da patente, ressalvadas as hipóteses de falta de exploração por razões legítimas".

No entanto, é difícil imaginar como o inventor poderá realizar a exploração econômica da sua invenção ou invento, até mesmo porque ele não dispõe de dependência industrial para tanto. Além disso, mesmo que dispusesse, ele não pode, diante da manutenção do vínculo empregatício, realizar concorrência desleal com o seu empregador.

$\mathrm{Na}$ inexistência deste vínculo também não será fácil vislumbrar a possibilidade do inventor negociar a sua invenção com outra empresa, pois se existissem reais possibilidades de obtenção de lucratividade com o invento, o seu ex-empregador não teria aberto mão de explorá-lo. Assim, é difícil imaginar que outra empresa tenha interesse na invenção ou invento, exceto se esta enxergar possibilidade de exploração não imaginada pelo exempregador.

Por fim, é possível que mesmo no caso da invenção mista exista mais de um empregado inventor. Nestes casos, o quantum cabível ao empregado inventor será dividido em quantos forem os inventores, nos ditames do $\S 1^{\circ}$,

\footnotetext{
103 Op. cit., p.280.

104 A falta de condições econômicas para a exploração da invenção ou invento pode ser um exemplo justificável para a inércia do empregador. Mas nada impede que diante desta possibilidade ele negocie com terceiros a exploração deste. Vale lembrar, que nesta hipótese, poderá o empregado exercer direito de preferência, em igualdade de condições com terceiros, pois o $\S 4^{\circ}$, do artigo 91, da Lei 9.279/1996, assim dispõe: "No caso de cessão, qualquer dos cotitulares, em igualdade de condições, poderá exercer o direito de preferência".
} 
do artigo 91, da Lei 9.279/1996 ${ }^{105}$. Neste ponto, Orlando Gomes e Elson

Gottschalk fazem observação importante, que poderia desnaturar esta propriedade mista:

"A invenção de empresa ou de estabelecimento é aquela realizada gradualmente pelo trabalho de vários empregados cuja experiência e pesquisa inventiva se entrelaçam de tal sorte que não se pode designar o verdadeiro responsável (Engler). A invenção decorre da experiência prática, dos trabalhos preparatórios, dos meios auxiliares da empresa de modo a não se poder identificar o inventor, dado que a invenção é fruto da atividade profissional dos que estão na empresa ou dos que dela já saíram. A doutrina universal admite que em tais circunstâncias o proprietário da empresa poderá vindicar a propriedade da patente" ${ }^{106}$.

Com base nesta ressalva feita, o Tribunal Regional do Trabalho, da $4^{\mathrm{a}}$ Região, assim decidiu:

"A testemunha (...) declarou que ele e o reclamante faziam montagem de protótipos. O próprio demandante esclareceu que todas as equipes de projeto trabalhavam com os mesmos produtos, com total capacidade para desenvolvê-los, em todas as linhas de alto-falantes. Nesse contexto, entendo que a prova carreada demonstra que não houve invento produzido apenas pelo autor, mas produto do resultado de uma equipe formada para tal fim, inexistindo, portanto, direito à indenização, mormente levando em conta que o invento foi decorrente das atribuições para as quais o empregado foi contratado"107.

Esta classificação de invenção de empresa ou de estabelecimento, no entanto, não é muito utilizada pelos autores atuais. Assim, a desnaturação do direito de indenização, realizado pelo respectivo tribunal, poderia ter sido feita, simplesmente, com a atual classificação de invenção de serviço; ainda que, como no caso concreto, não houvesse cláusula contratual expressa que atribuísse à empresa a única titularidade do invento.

\footnotetext{
${ }^{105}$ Eis a redação do respectivo parágrafo: "Sendo mais de um empregado, a parte que lhes couber será dividida igualmente entre todos, salvo ajuste em contrário".

${ }_{106}$ Op. cit., p.223.

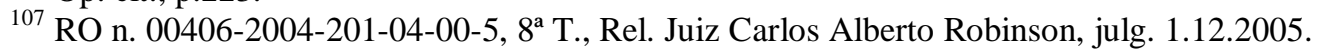




\section{Conclusão}

Diante de todo o acima abordado, é possível concluir que a análise dos direitos do empregado, no caso deste desenvolver invento ou invenção na constância da relação empregatícia, varia de acordo com as circunstâncias de cada caso concreto. No entanto, é possível delinear uma trajetória que, se seguida, facilitará o enquadramento desta exteriorização da atividade inventiva em uma das modalidades de invento ou invenção, quais sejam: de serviço, mistas ou livres.

Assim, primeiramente há que se perquirir as funções para as quais o empregado foi inicialmente contratado. Dessa forma, se contratado para desempenhar a atividade inventiva, e se a sua remuneração for compatível com o exercício desta função, tendo em vista os proveitos econômicos vindouros, não restam dúvidas, está invenção ou invento será de serviço, haja vista que o escopo da contratação visava exatamente àquela dada criação.

Nestes casos, o contrato de emprego, com previsão expressa neste sentido, reforça que a titularidade da invenção recairá sobre o empregador. No entanto, nada impede que, mesmo diante da ausência de contrato formal, a invenção seja tida como de serviço, desde que se prove o escopo da contratação e a compatibilidade do salário com as funções desempenhadas.

No entanto, caso o empregador direcione o empregado apenas posteriormente para o desempenho da atividade inventiva, ele deverá compatibilizar o salário do empregado para tanto, sob pena das criações, oriundas deste vínculo empregatício, serem tidas como mistas. Além disso, não basta que o empregador, com o escopo de elidir a invenção mista ou livre, insira cláusula de cessão de inventos futuros no contrato do empregado, pois o que se deve investigar é o objetivo inicial da contratação, pois, se estanho for à atividade inventiva, a invenção ou inventos não serão concebidos como de serviço.

Em segundo lugar, há que se vislumbrar se o empregado se utilizou, ou não, de recursos do empregador para o desempenho e concretização da atividade inventiva. Caso o invento seja totalmente desvinculado dos recursos financeiros, materiais e humanos do empregador, bem como caso tenha sido desenvolvido 
pelo empregado fora de seu ambiente laboral, o invento ou invenção será livre, ou seja, de propriedade exclusiva do empregado.

Mas, caso haja a colaboração do empregador, mesmo que este não tenha ciência de que auxiliou o empregado para a obtenção do resultado, ele fará jus, nos termos da lei, a um licenciamento exclusivo para explorar economicamente o invento ou invenção, pois consolidado estará o condomínio legal entre empregado e empregador, devendo, nestes termos, este último dividir os lucros auferidos com o inventor, mediante justa remuneração, como sói de ocorrer nas invenções ou inventos mistos.

Apesar destas considerações, é importante frisar que não basta enquadrar a atividade inventiva como livre, mista ou de serviço, pois a grande dificuldade prática, que transpassa o texto legal, consiste em delinear as peculiaridades técnicas de cada invenção ou invento para extrair a justa remuneração do empregado inventor. Principalmente porque a empresa exploradora da atividade inventiva, em grande parte dos casos, tenta minimizar a importância tecnológica e o impacto social do invento ou invenção para tentar se furtar ao pagamento do que é devido ao empregado inventor.

Nesta seara, é possível concluir que mais do que conhecer a interpretação do texto legal e as peculiaridades do contrato de emprego, para dirimir as lides concretas, o magistrado deverá ser respaldado por um estudo de viabilidade técnica e econômica do invento, para que o pólo fraco dessa relação empregatícia não se veja prejudicado por eventuais dissimulações patronais. 


\section{Referências Bibliográficas}

ABRÃO, Eliane Yachoub (organizadora), Propriedade Imaterial: Direitos Autorais, Propriedade Industrial e Bens de Personalidade, São Paulo: Editora Senac, 2006.

BARBOSA, Antonio Luiz Figueira, Sobre a Propriedade do Trabalho Intelectual: uma Perspectiva Crítica, Rio de Janeiro: Editora UFRJ, 1999.

BARBOSA, Denis Borges, A Propriedade Intelectual no Século XXI, Rio de Janeiro: Editora Lumen Juris, 2009, pp. 243-289.

BARBOSA, Denis Borges, Atividade Inventiva: Objetividade do Exame, in A Propriedade Intelectual no Século XXI - Estudos de Direito, Rio de Janeiro: Lumen Juris, 2009.

BARBOSA, DENIS BORGES, Da Noção de Bens Imateriais, Disponível em <http://www.denisbarbosa.addr.com/136.doc>. Acesso em: 15 mai. 2009.

BARBOSA, Denis Borges, O Comércio Internacional, O Desenvolvimento Econômico e Social e Seus Reflexos na Ordem Internacional da Propriedade Intelectual, in Patrícia Luciane de Carvalho (Org.), Propriedade Intelectual: Estudos em Honra à Professora Maristela Basso, Curitiba: Juruá, 2005, pp. 17-39.

BARBOSA, Denis Borges, Uma Introdução à Propriedade Intelectual, Rio de Janeiro: Editora Lumen Juris, 2003.

BARBOSA, Denis Borges, Usucapião de Patentes e Outros Estudos de Propriedade Intelectual, Rio de Janeiro: Lumen Juris, 2006.

BARBOSA, Gustavo José Ferreira, A Introdução no Nosso Ordenamento Jurídico do Requisito da Atividade Inventiva como Condição Legal para a Concessão de uma Patente de Invenção, in Revista Forense, vol. 339, Rio de Janeiro: Forense, 1997, pp. 85-108.

BASTOS, Celso Ribeiro; MARTINS, Ives Gandra, Comentários à Constituição do Brasil, vol. II, São Paulo: Editora Saraiva, 2001. 
BELMONTE, Alexandre Agra, Danos Morais no Direito do Trabalho, Rio de Janeiro: Renovar, 2007.

CARRION, Valentin, Comentários à Consolidação das Leis do Trabalho, São Paulo: Editora Saraiva, 2004.

CARVALHO, Augusto César Leite de, Direito Individual do Trabalho, Rio de Janeiro: Editora Forense, 2004.

CARVALHO, Nuno T. P., Os Inventos de Empregados na Nova Lei de Patentes - II, in Revista da ABPI, n. 23, Rio de Janeiro: Garilli Gráfica, 1996, pp. 3-37.

CARVAlHO, Nuno T. P., Os Inventos de Empregados na Nova Lei de Patentes - I, in Revista da ABPI, n. 22, Rio de Janeiro: Garilli Gráfica, 1996, pp. 3-33.

CASSAR, Vólia Bomfim, Direito do Trabalho, Niterói: Impetus, 2008.

CERQUEIRA, João da Gama, Tratado da Propriedade Industrial, vol. I, São Paulo: Editora RT, 1982.

CHAVES, Antonio, Os Direitos do Inventor, in Revista Forense, vol. 265, São Paulo, 1979, pp. 4-54.

CORREA, José Antonio B. L. Faria, A Proteção da Criação Intelectual Conforme o Objeto da Obra, in Revista da ABPI, n64, São Paulo, 2003, pp. 67-69.

CRETELLA JÚNIOR, José, Comentários à Constituição Brasileira de 1988, vol. I, São Paulo: Forense Universitária, 1989.

DELGADO, Maurício Godinho, Direitos da Personalidade (Intelectuais e Morais) e Contrato de Emprego, in Revista do Tribunal Regional do Trabalho da $3^{a}$ Região, Belo Horizonte, n. 60, 1999, pp. 95 - 107.

DI BLASI, Clésio Gabriel, A Propriedade Industrial, Rio de Janeiro: Editora Guanabara Dois, 1982.

DOMINGUES, Douglas Gabriel, Direito Industrial: Patentes, Rio de Janeiro: Forense, 1980. 
FERREIRA FILHO, Manoel Gonçalves, Comentários à Constituição Federal de 1988, vol. I, São Paulo: Editora Saraiva, 1990.

FERREIRA, Pinto, Comentários à Constituição Brasileira, vol. I, São Paulo: Editora Saraiva, 1989.

FLORINDO, Valdir, A Justiça do Trabalho e o Dano Moral Decorrente da Relação de Emprego, in Revista de Direito do Trabalho, n. 27, Rio de Janeiro, 1995, pp. 321-323.

FRANZOSI, Mario, L'invenzione, Milano: Giuffrè, 1995.

GANDELMAN, Marisa, Poder e Conhecimento na Economia Global: O Regime Internacional da Propriedade Intelectual da sua Formação às Regras de Comércio Atuais, Rio de Janeiro: Editora Civilização Brasileira, 2004.

GRAU-KUNTZ, Karin, Direito de Patentes - Sobre a Interpretação do Artigo $5^{\circ}$, XXIX da Constituição Brasileira, in Revista da ABPI, n. 98, Rio de Janeiro: Garilli Gráfica, 2009.

GRECO, Paolo; VERCELLONE, Paolo, Le invenzioni e i modelli industrialli, Torino: UTET, 1968.

HAND, John R. M.; LEV, Baruch, Introduction and Overview, in Intangible Assets: Values, Measures, and Risks, New York: Oxford University Press, 2003, pp. 1-2.

Instituto Dannemann Siemsen de Estudo de Propriedade Industrial, Comentários à Lei da Propriedade Industrial, Rio de Janeiro: Renovar, 2005.

LESSIG, Lawrence, Cultura Livre, Disponível em <http://www.rautu.unicamp.br/nou-rau/softwarelivre/document/?view=144>. Acesso em: 15 mai. 2009.

LOUREIRO, Luiz Guilherme de A. V., A Lei de Propriedade Industrial Comentada, São Paulo: Lejus, 1999.

LUZZATTO, Enrico, Trattato Generale delle Privative Industriali, vol. I, Milano: Editore Pilade Rocco, 1914.

MARINONI, Luiz Guilherme, Marca Comercial, Direito de Invento, Direito Autoral etc. Impropriedade do Uso das Ações Possessória, Cominatória e 
Cautelar. Cabimento da Ação Inibitória, in Revista dos Tribunais, vol. 768, São Paulo: Editora RT, 1999, pp. 21-38.

MARTINS, Sérgio Pinto, Comentários à CLT, São Paulo: Atlas, 2003.

MENDONÇA, José Xavier Carvalho de, Direito Comercial Brasileiro, vol. V, Rio de Janeiro: Bastos, 1938.

MIRANDA, Francisco Cavalcanti Pontes de, Comentários à Constituição de 1967, Tomo V, São Paulo: Revista dos Tribunais, 1970.

MORAES FILHO, Evaristo de, Introdução ao Direito do Trabalho, São Paulo: Editora LTr, 2003.

NAKAMURA, Leonard, A trillion dollars a year in intangible investment and the New Economy, in Intangible Assets: Values, Measures, and Risks, New York: Oxford University Press, 2003, pp.19-47.

NASCIMENTO, Amauri Mascaro, Curso de Direito do Trabalho, São Paulo: Editora Saraiva, 2004.

NASCIMENTO, João Paulo Capella, A Natureza Jurídica do Direito Sobre os Bens Imateriais, in Revista da ABPI, n²8, São Paulo, 1997, pp. 23-32.

Orlando Gomes e Elson Gottschalk, Curso de Direito do Trabalho, Rio de Janeiro: Forense, 2007.

RODRIGUEZ, Américo Plá, Princípios de Direito do Trabalho, São Paulo: LTr, 2000, p. 340.

SAAD, Eduardo Gabriel, Consolidação das Leis do Trabalho, São Paulo: Editora LTr, 1999.

SABOIA, Marcelo Rocha, A Propriedade Industrial e sua Tutela Jurídica, in Revista da ABPI, n ${ }^{\circ}$, São Paulo, 1995, pp. 3-13.

SOUZA, Ana Cristina França de, Avaliação de Propriedade Intelectual e Ativos Intangíveis, in Revista da ABPI, n³9, São Paulo, 1999, pp. 9-14.

STOLFI, Nicola, La Proprietà Intellettuale, vol. I, Editrice Torinese, 1915.

SÜSSEKIND, Arnaldo, Curso de Direito do Trabalho, Rio de Janeiro: Renovar, 2004. 
SÜSSEKIND, Arnaldo; FALCÃO, Alcino Pinto; MELLO, Celso Albuquerque; SOBRINHO, Manoel de Oliveira Franco; CUNHA, Fernando Whitaker da, Comentários à Constituição, vol. I, Rio de Janeiro: Livraria Freitas de Bastos, 1990.

SÜSSEKIND, Arnaldo; TEIXEIRA FILHO, João de Lima, Instituições de Direito do Trabalho, vol. I, São Paulo: LTr, 2005.

ZANGRANDO, Carlos Henrique da Silva, Resumo do Direito do Trabalho, Rio de Janeiro: Trabalhistas, 2003. 